\title{
LEVEL II SCOUR ANALYSIS FOR BRIDGE 53 (CHESTH01180053) on TOWN HIGHWAY 118, crossing the WILLIAMS RIVER, \\ CHESTER, VERMONT
}

Open-File Report 97-769

Prepared in cooperation with

VERMONT AGENCY OF TRANSPORTATION

and

FEDERAL HIGHWAY ADMINISTRATION

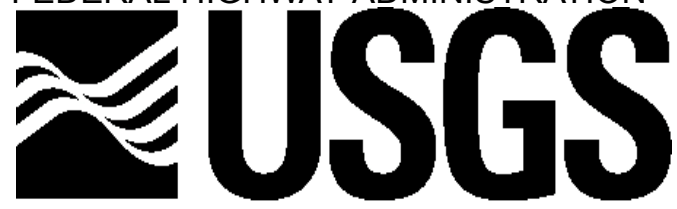

science for a changing world

U.S. Department of the Interior

U.S. Geological Survey 


\section{LEVEL II SCOUR ANALYSIS FOR BRIDGE 53 (CHESTH01180053) on TOWN HIGHWAY 118, crossing the WILLIAMS RIVER, CHESTER, VERMONT \\ By LORA K. STRIKER AND LAURA MEDALIE}

U.S. Geological Survey Open-File Report 97-769

Prepared in cooperation with

VERMONT AGENCY OF TRANSPORTATION

and

FEDERAL HIGHWAY ADMINISTRATION 


\title{
U.S. DEPARTMENT OF THE INTERIOR BRUCE BABBITT, Secretary
}

\author{
U.S. GEOLOGICAL SURVEY \\ Mark Schaefer, Acting Director
}

For additional information write to:

District Chief

U.S. Geological Survey 361 Commerce Way

Pembroke, NH 03275-3718
Copies of this report may be purchased from:

U.S. Geological Survey

Branch of Information Services

Open-File Reports Unit

Box 25286

Denver, CO 80225-0286 


\section{CONTENTS}

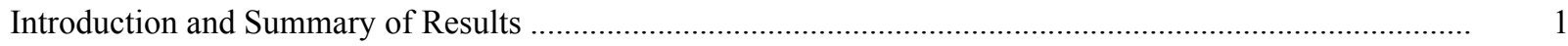

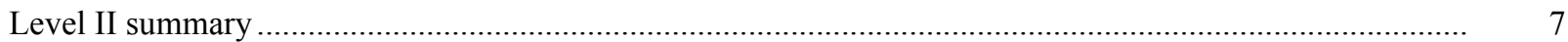

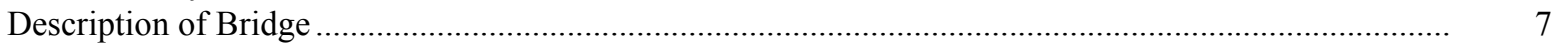

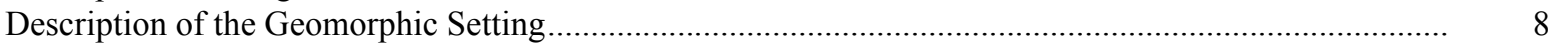

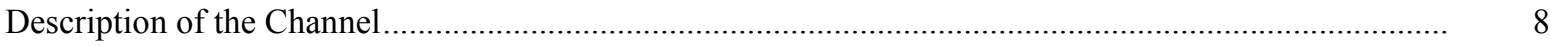

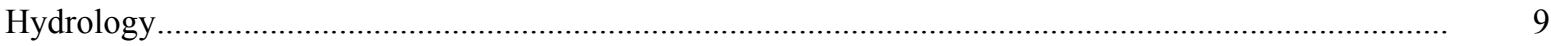

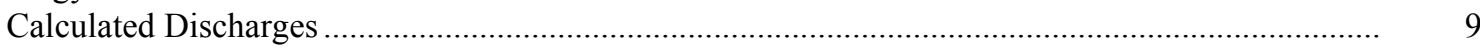

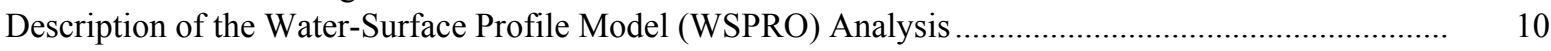

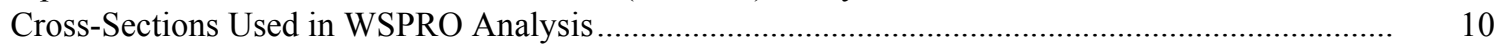

Data and Assumptions Used in WSPRO Model ...................................................................... 11

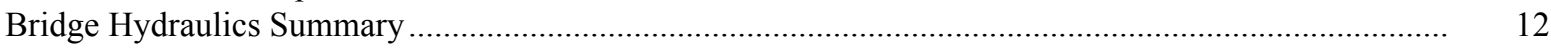

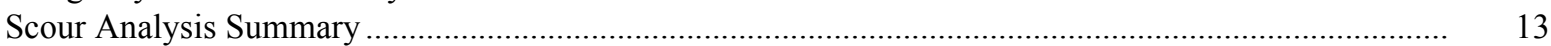

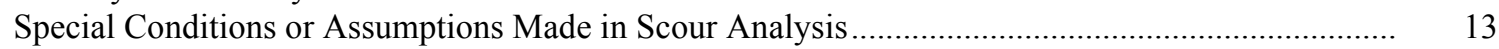

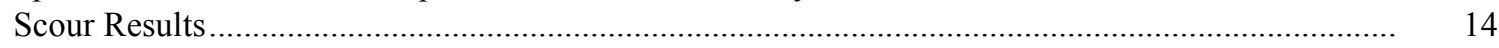

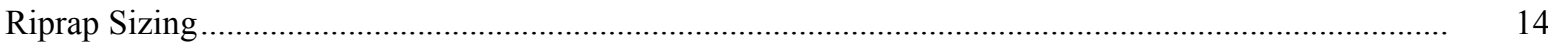

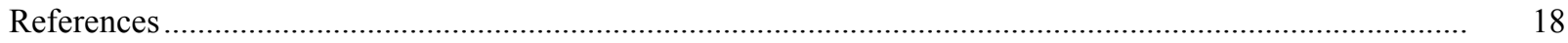

Appendixes:

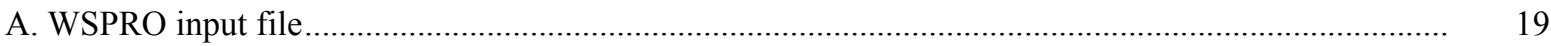

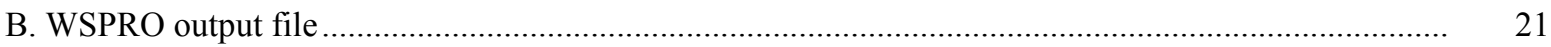

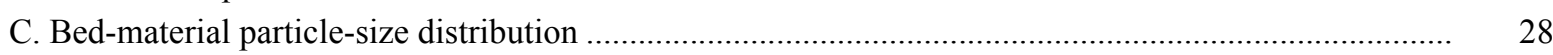

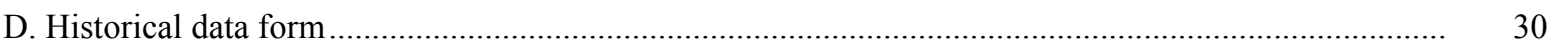

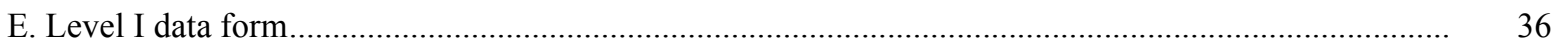

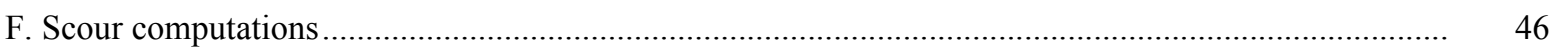

\section{FIGURES}

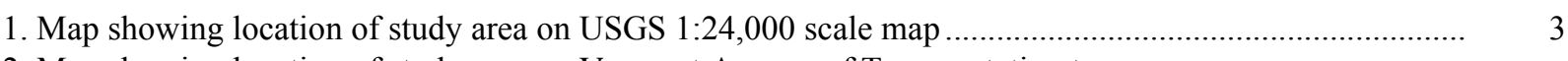

2. Map showing location of study area on Vermont Agency of Transportation town

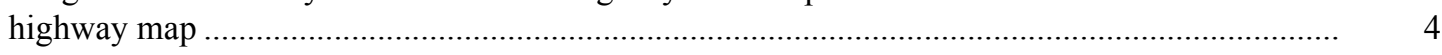

3. Structure CHESTH01180053 viewed from upstream (September 17, 1996) ......................................... 5

4. Downstream channel viewed from structure CHESTH01180053 (September 17, 1996)........................ 5

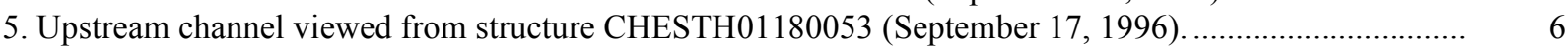

6. Structure CHESTH01180053 viewed from downstream (September 17, 1996) .................................... 6

7. Water-surface profiles for the 100- and 500-year discharges at structure

CHESTH01180053 on Town Highway 118, crossing the Williams River,

Chester, Vermont.

8. Scour elevations for the 100- and 500-year discharges at structure

CHESTH01180053 on Town Highway 118, crossing the Williams River,

Chester, Vermont.

\section{TABLES}

1. Remaining footing/pile depth at abutments for the 100-year discharge at structure

CHESTH01180053 on Town Highway 118, crossing the Williams River,

Chester, Vermont

2. Remaining footing/pile depth at abutments for the 500-year discharge at structure

CHESTH01180053 on Town Highway 118, crossing the Williams River,

Chester, Vermont 


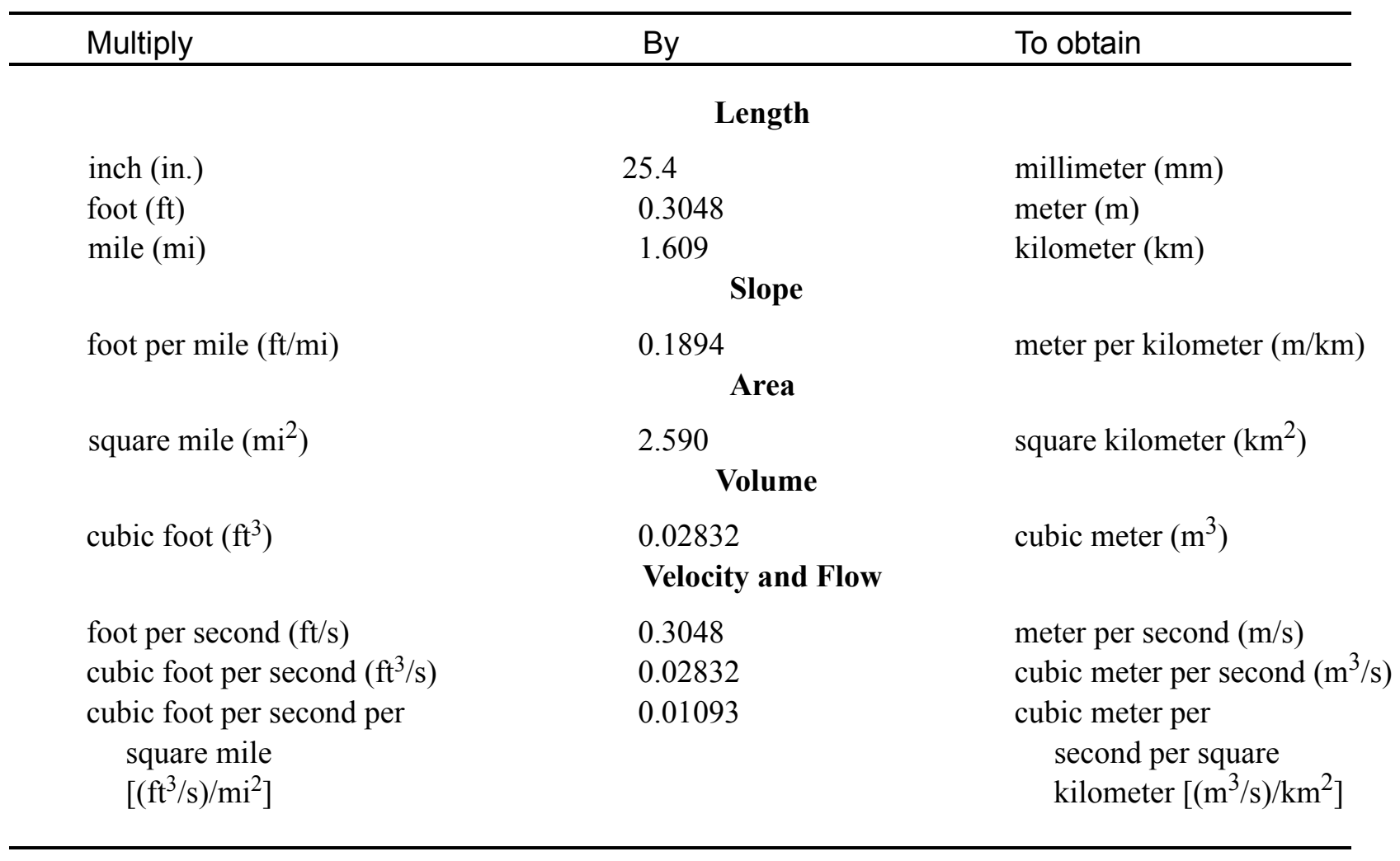

\section{OTHER ABBREVIATIONS}

$\begin{array}{lrlr}\mathrm{BF} & \text { bank full } & \text { LWW } & \text { left wingwall } \\ \mathrm{cfs} & \text { cubic feet per second } & \text { MC } & \text { main channel } \\ \mathrm{D}_{50} & \text { median diameter of bed material } & \text { RAB } & \text { right abutment } \\ \mathrm{DS} & \text { downstream } & \text { RABUT } & \text { face of right abutment } \\ \mathrm{elev} & \text { elevation } & \text { RB } & \text { right bank } \\ \mathrm{f} / \mathrm{p} & \text { flood plain } & \text { ROB } & \text { right overbank } \\ \mathrm{ft}^{2} & \text { square feet } & \text { RWW } & \text { right wingwall } \\ \mathrm{ft} / \mathrm{ft} & \text { feet per foot } & \text { TH } & \text { town highway } \\ \mathrm{JCT} & \text { junction } & \text { UB } & \text { under bridge } \\ \mathrm{LAB} & \text { left abutment } & \text { US } & \text { upstream } \\ \mathrm{LABUT} & \text { face of left abutment } & \text { USGS } & \text { United States Geological Survey } \\ \mathrm{LB} & \text { left bank } & \text { VTAOT Vermont Agency of Transportation } \\ \mathrm{LOB} & \text { left overbank } & \text { WSPRO } & \text { water-surface profile model }\end{array}$

In this report, the words "right" and "left" refer to directions that would be reported by an observer facing downstream. Sea level: In this report, "sea level" refers to the National Geodetic Vertical Datum of 1929-- a geodetic datum derived from a general adjustment of the first-order level nets of the United States and Canada, formerly called Sea Level Datum of 1929.

In the appendices, the above abbreviations may be combined. For example, USLB would represent upstream left bank. 


\title{
LEVEL II SCOUR ANALYSIS FOR BRIDGE 53 (CHESTH01180053) ON TOWN HIGHWAY 118, CROSSING THE WILLIAMS RIVER, CHESTER, VERMONT
}

\author{
By Lora K. Striker and Laura Medalie
}

\section{INTRODUCTION AND SUMMARY OF RESULTS}

This report provides the results of a detailed Level II analysis of scour potential at structure CHESTH01180053 on Town Highway 118 crossing the Williams River, Chester, Vermont (figures 1-8). A Level II study is a basic engineering analysis of the site, including a quantitative analysis of stream stability and scour (U.S. Department of Transportation, 1993). Results of a Level I scour investigation also are included in Appendix E of this report. A Level I investigation provides a qualitative geomorphic characterization of the study site. Information on the bridge, gleaned from Vermont Agency of Transportation (VTAOT) files, was compiled prior to conducting Level I and Level II analyses and is found in Appendix D.

The site is in the New England Upland section of the New England physiographic province in southeastern Vermont. The $20.8-\mathrm{mi}^{2}$ drainage area is in a predominantly rural and forested basin. In the vicinity of the study site, the surface cover is predominantly suburban while the right bank upstream is pasture. There is a house on the right bank downstream and VT 103 runs parallel to the river along the left bank.

In the study area, the Williams River has an incised, straight channel with a slope of approximately $0.005 \mathrm{ft} / \mathrm{ft}$, an average channel top width of $64 \mathrm{ft}$ and an average bank height of $7 \mathrm{ft}$. The channel bed material ranges from sand to boulder with a median grain size $\left(\mathrm{D}_{50}\right)$ of $58.0 \mathrm{~mm}(0.190 \mathrm{ft})$. The geomorphic assessment at the time of the Level I and Level II site visit on September 17, 1996, indicated that the reach was stable.

The Town Highway 118 crossing of the Williams River is a 43-ft-long, one-lane bridge consisting of one 40-foot steel-beam span (Vermont Agency of Transportation, written communication, April 6, 1995). The opening length of the structure parallel to the bridge face is $37.6 \mathrm{ft}$. The bridge is supported by vertical, concrete abutments with wingwalls. The channel is skewed approximately 5 degrees to the opening while the computed openingskew-to-roadway is 10 degrees. 
A scour hole $0.5 \mathrm{ft}$ deeper than the mean thalweg depth was observed at both abutments during the Level I assessment. Scour protection measures at the site include: type-3 stone fill (less than 48 inches diameter) along the left bank upstream and downstream and type-2 stone fill (less than 36 inches diameter) along the entire base length of the upstream left wingwall, at the upstream end of the left abutment, and at the upstream end of the downstream left wingwall. Additional details describing conditions at the site are included in the Level II Summary and Appendices D and E.

Scour depths and recommended rock rip-rap sizes were computed using the general guidelines described in Hydraulic Engineering Circular 18 (Richardson and others, 1995) for the 100- and 500-year discharges. In addition, the incipient roadway-overtopping discharge is determined and analyzed as another potential worst-case scour scenario. Total scour at a highway crossing is comprised of three components: 1) long-term streambed degradation; 2) contraction scour (due to accelerated flow caused by a reduction in flow area at a bridge) and; 3 ) local scour (caused by accelerated flow around piers and abutments). Total scour is the sum of the three components. Equations are available to compute depths for contraction and local scour and a summary of the results of these computations follows.

Contraction scour for all modelled flows was $0.0 \mathrm{ft}$. Abutment scour ranged from 5.8 to 6.8 $\mathrm{ft}$ at the left abutment and 9.4 to $14.4 \mathrm{ft}$ at the right abutment. The worst-case abutment scour occurred at the incipient roadway-overtopping discharge. Additional information on scour depths and depths to armoring are included in the section titled "Scour Results". Scoured-streambed elevations, based on the calculated scour depths, are presented in tables 1 and 2. A cross-section of the scour computed at the bridge is presented in figure 8. Scour depths were calculated assuming an infinite depth of erosive material and a homogeneous particle-size distribution.

It is generally accepted that the Froehlich equation (abutment scour) gives "excessively conservative estimates of scour depths" (Richardson and others, 1995, p. 47). Usually, computed scour depths are evaluated in combination with other information including (but not limited to) historical performance during flood events, the geomorphic stability assessment, existing scour protection measures, and the results of the hydraulic analyses. Therefore, scour depths adopted by VTAOT may differ from the computed values documented herein. 


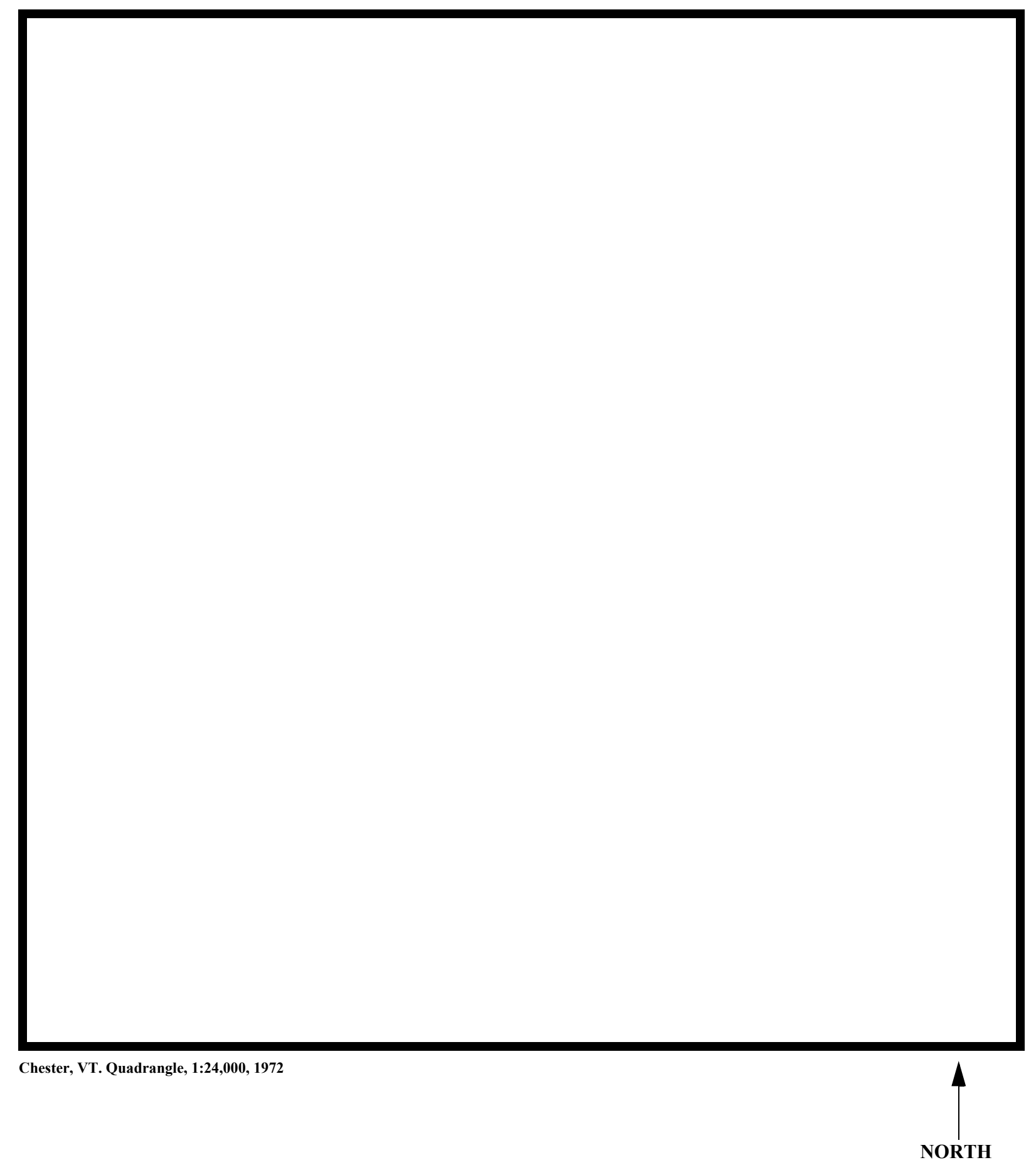

Figure 1. Location of study area on USGS 1:24,000 scale map. 
Figure 2. Location of study area on Vermont Agency of Transportation town highway map. 

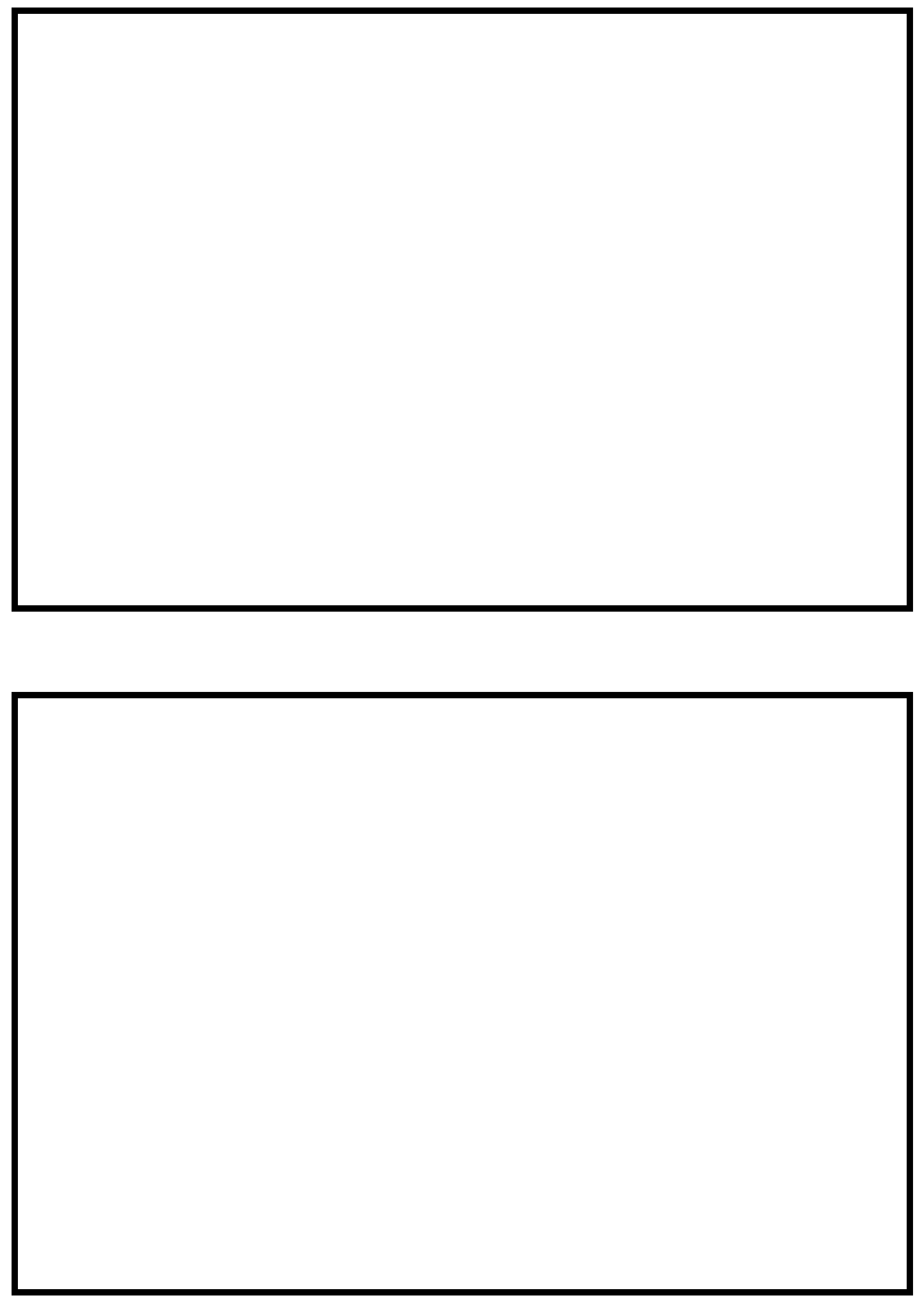

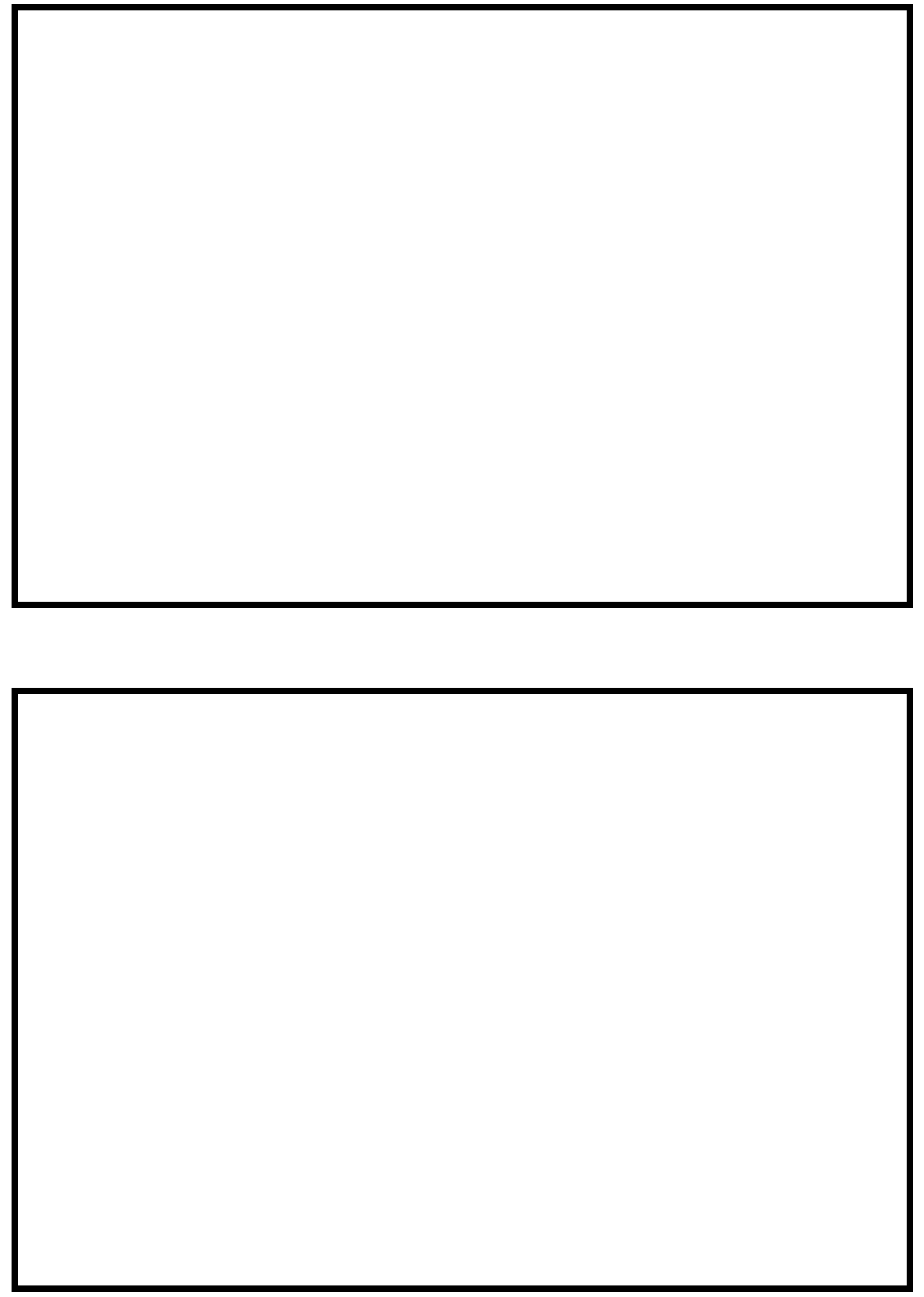


\section{LEVEL II SUMMARY}

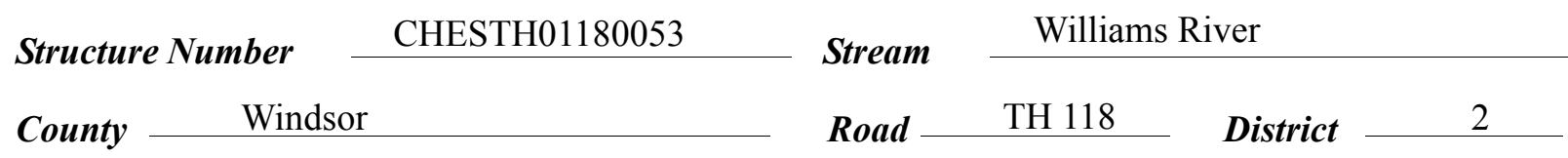

\section{Description of Bridge}

Bridge length $\frac{43}{4}$ ft Bridge width $\frac{11.5}{f t}$ Max span length $\stackrel{40}{f t}$ Alignment of bridge to road (on curve or straight) Abutment type Vertical, concrete

$\begin{array}{lll}\text { Abutment type } & \text { Embankment type } \\ \text { Stone fill on abutment? } & \text { Yes } & \text { nato af insnortinn }\end{array}$
on curve

Type-2, at the upstream end of the left abutment, along the entire base length of the upstream left wingwall, and at the upstream end of the downstream left wingwall.

Abutments and wingwalls are concrete. There is $0.5 \mathrm{ft}$ of channel scour on the left and right abutments. The right abutment footing is exposed $0.5 \mathrm{ft}$ at the upstream end.

Yes

\section{5} No

Is bridge skewed to flood flow according to 'survey? Angle

Debris accumulation on bridge at time of Level I or Level II site visit:

Date af insnortion
$\underline{0}$ $\begin{gathered}\text { Percent of ahannal } \\ \text { blocked inortzontaty }\end{gathered}$

Level I $\underline{96}$
0 Percent of 0917$]^{-1 e l}$
blocked verticatty 0

Level II Low. There is evidence of ice jams due to minor scraping of bark on trees upstream of the bridge.

Potential for debris

None, 09/17/96.

Dosrriho any, foaturos noar ar at tho hridoo that mav, affort flow, (includo ahsorvation dato) 


\section{Description of the Geomorphic Setting}

General topography The channel is located within a moderate relief valley with a flat flood plain and steep valley wall on the left bank.

Geomorphic conditions at bridge site: downstream (DS), upstream (US)

Date of inspection $\quad 09 / 17 / 96$

DS left: $\quad$ Steep channel bank to a narrow flood plain

DS right: $\quad$ Steep channel bank to a narrow flood plain

US left: $\quad$ Steep channel bank to a narrow flood plain

US right: $\quad$ Steep channel bank to a narrow flood plain

\section{Description of the Channel}

\begin{tabular}{|c|c|c|c|}
\hline \multirow[b]{2}{*}{ Average top width } & 64 & \multirow[b]{2}{*}{ Average depth } & \multirow[b]{2}{*}{ Sand- boulder } \\
\hline & Sand- boulder & & \\
\hline Predominant bed m & & Bank material & he stream is \\
\hline
\end{tabular}

equiwidth, straight, and stable with alluvial channel boundaries.

Vegetative co 1 Brush to VT 103

DS left: $\quad$ Brush with a few trees, house, and lawn on the overbank (flood plain)

DS right: $\quad$ Grass and weeds to VT 103

US left: $\quad$ Trees and brush

US right: $\quad$ Yes

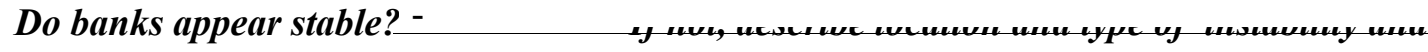

date of observation.

None, 09/17/96.

Describe any obstructions in channel and date of observation. 


\section{Hydrology}

Drainage area $\stackrel{20.8}{\boldsymbol{m i}^{2}}$

Percentage of drainage area in physiographic provinces: (approximate)

Physiographic province/section New England/New England Upland
Percent of drainage area 100

Is drainage area considered rural or urban? Rural Describe any significant

urbanization: There is a house on the downstream right overbank area.

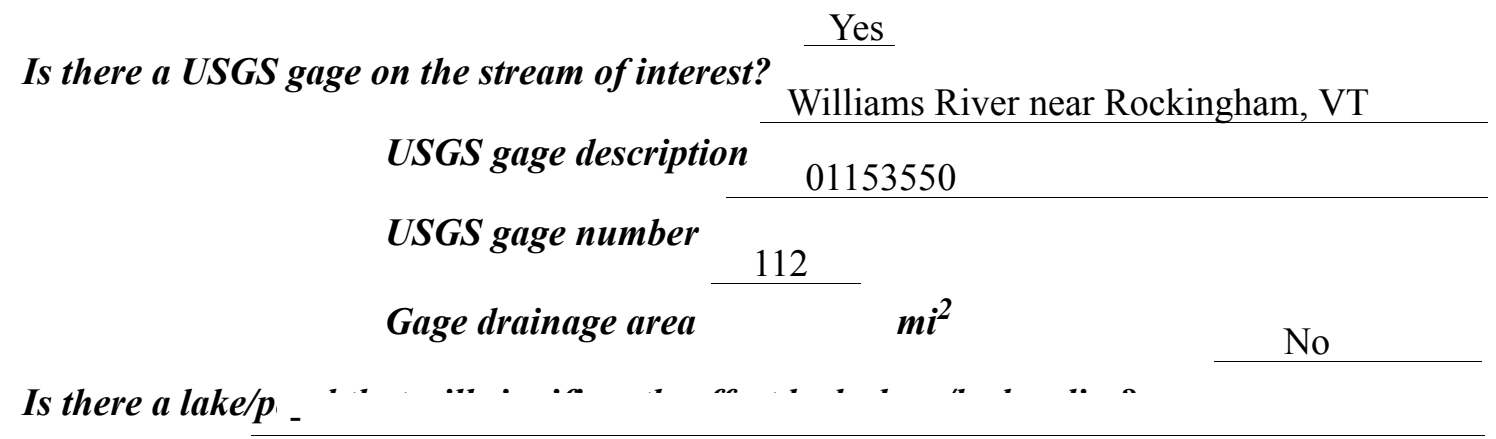

The 100- and 500-year discharges are based on a

drainage area relationship.[(20.8/21.3)exp 0.75] with discharge estimates from the Williams River upstream of Whitmore Brook. Whitmore Brook joins the Williams River downstream of this site. The WIlliams River has flood frequency estimates available from the Flood Insurance Study (FIS) for the town of Chester (Federal Emergency Management Agency, 1982). The drainage area above Whitmore Brook is 21.3 square miles. The discharges fall within range of several other empirical methods (Benson, 1962; Johnson and Tasker, 1974; FHWA, 1983; Potter, 1957a\&b; Talbot, 1887). 


\section{Description of the Water-Surface Profile Model (WSPRO) Analysis}

Datum for WSPRO analysis (USGS survey, sea level, VTAOT plans)

USGS survey

Datum tie between USGS survey and VTAOT plans

None.

Description of reference marks used to determine USGS datum. $\quad$ RM1 is a chiseled X on

top of the downstream end of the right abutment (elev. $497.76 \mathrm{ft}$, arbitrary survey datum). RM2

is a National Geodetic Survey brass tablet located 10' DS of the bridge on the left bank between

the Williams River and VT 103 in a rock halfway up the bank labelled 'L61, 1980' (elev. 505.61

$\mathrm{ft}$, arbitrary survey datum).

\section{Cross-Sections Used in WSPRO Analysis}

\begin{tabular}{ccll}
\hline${ }^{1}$ Cross-section & $\begin{array}{c}\text { Section } \\
\text { Reference } \\
\text { Distance } \\
\text { (SRD) in feet }\end{array}$ & $\begin{array}{c}{ }^{2} \text { Cross-section } \\
\text { development }\end{array}$ & \multicolumn{1}{c}{ Comments } \\
\hline EXIT1 & -50 & 1 & Exit section \\
FULLV & 0 & 2 & $\begin{array}{l}\text { Downstream Full-valley } \\
\text { section (Templated from } \\
\text { EXITX) }\end{array}$ \\
BRIDG & 0 & 1 & $\begin{array}{l}\text { Bridge section } \\
\text { Road Grade section }\end{array}$ \\
RDWAY & 7 & 1 & $\begin{array}{l}\text { Modelled Approach sec- } \\
\text { tion (Templated from } \\
\text { APTEM) }\end{array}$ \\
APTEM & 51 & 2 & $\begin{array}{l}\text { Approach section as sur- } \\
\text { veyed (Used as a tem- } \\
\text { plate) }\end{array}$ \\
\hline
\end{tabular}

${ }^{1}$ For location of cross-sections see plan-view sketch included with Level I field form, Appendix E. For more detail on how cross-sections were developed see WSPRO input file. 


\section{Data and Assumptions Used in WSPRO Model}

Hydraulic analyses of the reach were done by use of the Federal Highway Administration's WSPRO step-backwater computer program (Shearman and others, 1986, and Shearman, 1990). The analyses reported herein reflect conditions existing at the site at the time of the study. Furthermore, in the development of the model it was necessary to assume no accumulation of debris or ice at the site. Results of the hydraulic model are presented in the Bridge Hydraulic Summary, Appendix B, and figure 7.

Channel roughness factors (Manning's " $n$ ") used in the hydraulic model were estimated using field inspections at each cross section following the general guidelines described by Arcement and Schneider (1989). Final adjustments to the values were made during the modelling of the reach. Channel " $\mathrm{n}$ " values for the reach ranged from 0.040 to 0.050 , and overbank " $\mathrm{n}$ " values ranged from 0.030 to 0.050 .

The starting water surface at the exit section (EXIT1) from each modelled discharge was taken from a rating curve developed using discharges and water surface elevations at the same

location from the FIS for the Town of Chester (Federal Emergency Management Agency, 1982). Since the discharges used in this model differed slightly from the FIS, the rating curve was used to calculate adjusted water surface elevations at the exit section.

The surveyed approach section (APTEM) was moved along the approach channel slope $(0.011 \mathrm{ft} / \mathrm{ft})$ to establish the modelled approach section (APPRO), one bridge length upstream of the upstream face as recommended by Shearman and others (1986). This location also provides a consistent method for determining scour variables. 


\section{Bridge Hydraulics Summary}

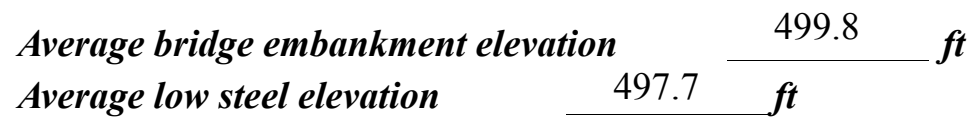

$$
\text { 100-year discharge } \quad 4,740 \quad \mathrm{ft}^{3} / \mathrm{s}
$$

Water-surface elevation in bridge opening $\quad 497.7 \quad f t$

Road overtopping? ___ Yes Discharge over road __ 2,250 $\mathrm{ft}^{3} / \mathrm{s}$

\begin{tabular}{lll} 
Area of flow in bridge opening & $315 \quad \mathrm{ft}^{2}$ \\
\cline { 2 - 3 } Average velocity in bridge opening & 7.9 & $\mathrm{ft} / \mathrm{s}$
\end{tabular}

$\begin{array}{llll}\text { Maximum WSPRO tube velocity at bridge } & 9.0 \mathrm{ft} / \mathrm{s}\end{array}$

Water-surface elevation at Approach section with bridge $\quad 501.1$

Water-surface elevation at Approach section without bridge $\quad 500.5$

Amount of backwater caused by bridge $\quad 0.6 \quad$ it

500-year discharge $\quad 6,950 \quad \mathrm{ft}^{3} / \mathrm{s}$

Water-surface elevation in bridge opening 497.7 ft

$\begin{array}{lllll}\text { Road overtopping? ___ Yes Discharge over road __ } \quad 4,740 & \mathrm{ft}^{3} / \mathrm{s}\end{array}$

$\begin{array}{llll}\text { Area of flow in bridge opening } & 315 & \boldsymbol{f t}^{2} & \\ \text { velocity in bridge opening } & & 7.1 \quad \mathrm{ft} / \mathrm{s}\end{array}$

Maximum WSPRO tube velocity at bridge 8.1 's

Water-surface elevation at Approach section with bridge $\quad 502.2$

Water-surface elevation at Approach section without bridge $\quad 502.1$

Amount of backwater caused by bridge $\quad 0.1$, $t$

Incipient overtopping discharge $\quad 2,660 \mathrm{ft}^{3} / \mathrm{s}$

Water-surface elevation in bridge opening $497.7 \quad t$

Area of flow in bridge opening $\quad 315 \quad \mathbf{f t}^{2}$

Average velocity in bridge opening $\quad 8.4 \quad \mathrm{ft} / \mathrm{s}$

Maximum WSPRO tube velocity at bridge $\quad 9.7 \mathrm{ft} / \mathrm{s}$

Water-surface elevation at Approach section with bridge

Water-surface elevation at Approach section without bridge

499.1

Amount of backwater caused by bridge $\quad 1.1$ it 


\section{Scour Analysis Summary}

\section{Special Conditions or Assumptions Made in Scour Analysis}

Scour depths were computed using the general guidelines described in Hydraulic Engineering Circular 18 (Richardson and others, 1995). Scour depths were calculated assuming an infinite depth of erosive material and a homogeneous particle-size distribution. The results of the 100- and 500-year scour analyses are presented in tables 1 and 2 and a graph of the scour depths is presented in figure 8 .

At this site, the 100-year, 500-year, and incipient discharges resulted in submerged orifice flow. Contraction scour at bridges with orifice flow is best estimated by use of the Chang pressure-flow scour equation (oral communication, J. Sterling Jones, October 4, 1996). Thus, contraction scour for these discharges was computed by use of the Chang equation (Richardson and others, 1995, p. 145-146).

For comparison, contraction scour for the discharges resulting in orifice flow was also computed by use of the Laursen clear-water contraction scour equation and the Umbrell pressure-flow equation (Richardson and others, 1995, p. 144). The results are presented in Appendix F. All calculations for the estimation of contraction scour at this site resulted in $0.0 \mathrm{ft}$.

Abutment scour was computed by use of the Froehlich equation (Richardson and others, 1995, p. 48, equation 28). Variables for the Froehlich equation include the Froude number of the flow approaching the embankments, the length of the embankment blocking flow, and the depth of flow approaching the embankment less any roadway overtopping.

The length to depth ratio of the embankment blocking flow exceeded 25 for the 100and 500-year discharges at both abutments. Although the HIRE equation (Richardson and others, 1993, p. 50, equation 25) generally is applicable when this ratio exceeds 25 , the results from the HIRE equation were not used. Hydraulic Engineering Circular 18 recommends that the field conditions be similar to those from which the HIRE equation was derived (Richardson and others, 1993). Since the equation was developed from Army Corp. of Engineers' data obtained for spurs dikes in the Mississippi River, the HIRE equation was not adopted for the narrow, incised, upland valley at this site. 


\section{Scour Results}

\section{0-yr discharge 500-yr discharge}

Contraction scour:

(Scour depths in feet)

Main channel

Live-bed scour

Clear-water scour

Depth to armoring

Left overbank

Right overbank

Local scour:

Abutment scour

Left abutment

5.8

6.5

6.8

9.4

$10.4-$

$14.4-$

Right abutment

Pier scour

Pier 1

Pier 2

Pier 3

\section{Abutments:}

Left abutment

Right abutment

Piers:

Pier 1

Pier 2

overtopping discharge 


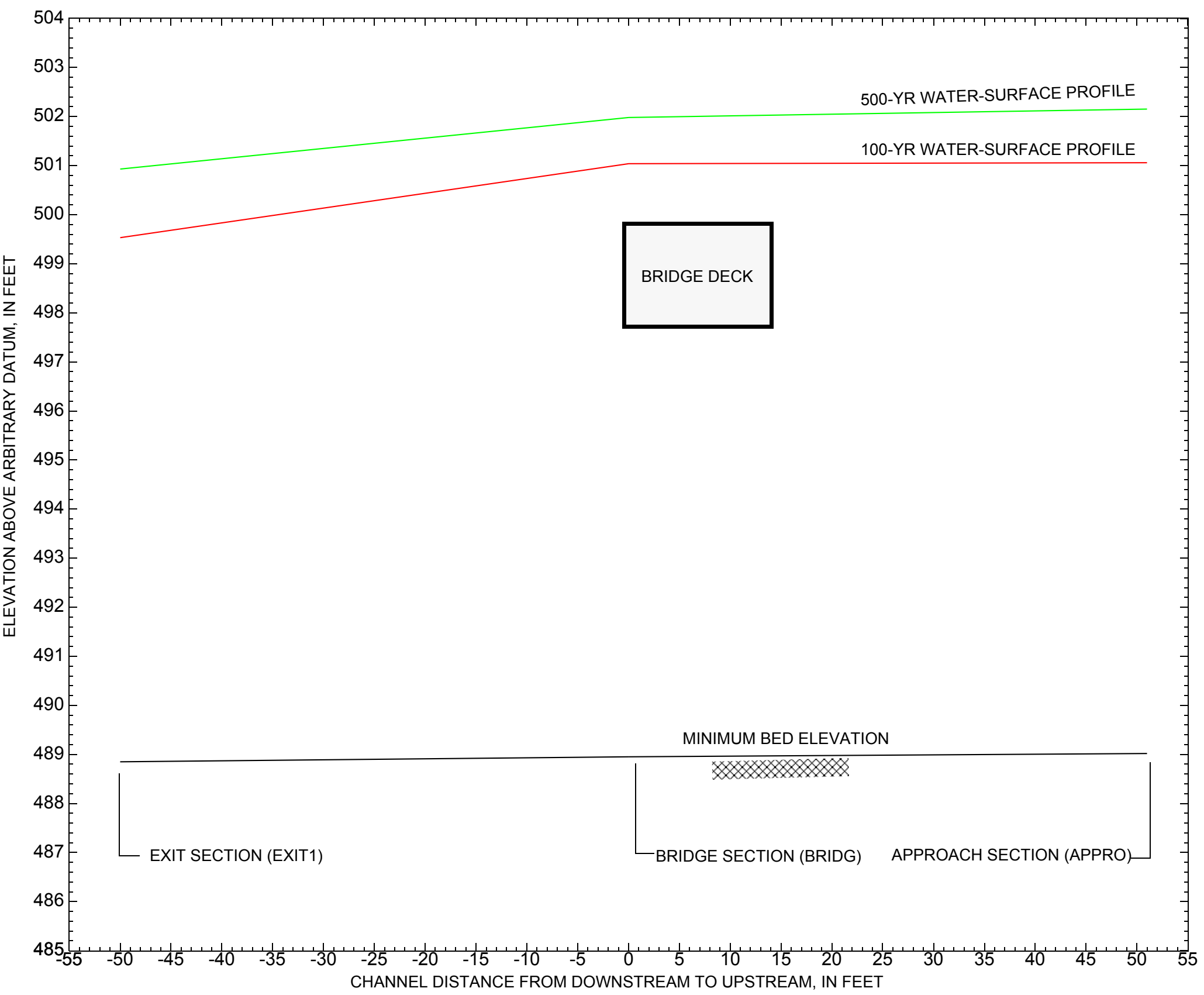

Figure 7. Water-surface profiles for the 100- and 500-year discharges at structure CHESTH01180053 on Town Highway 118, crossing the Williams River, Chester, Vermont. 


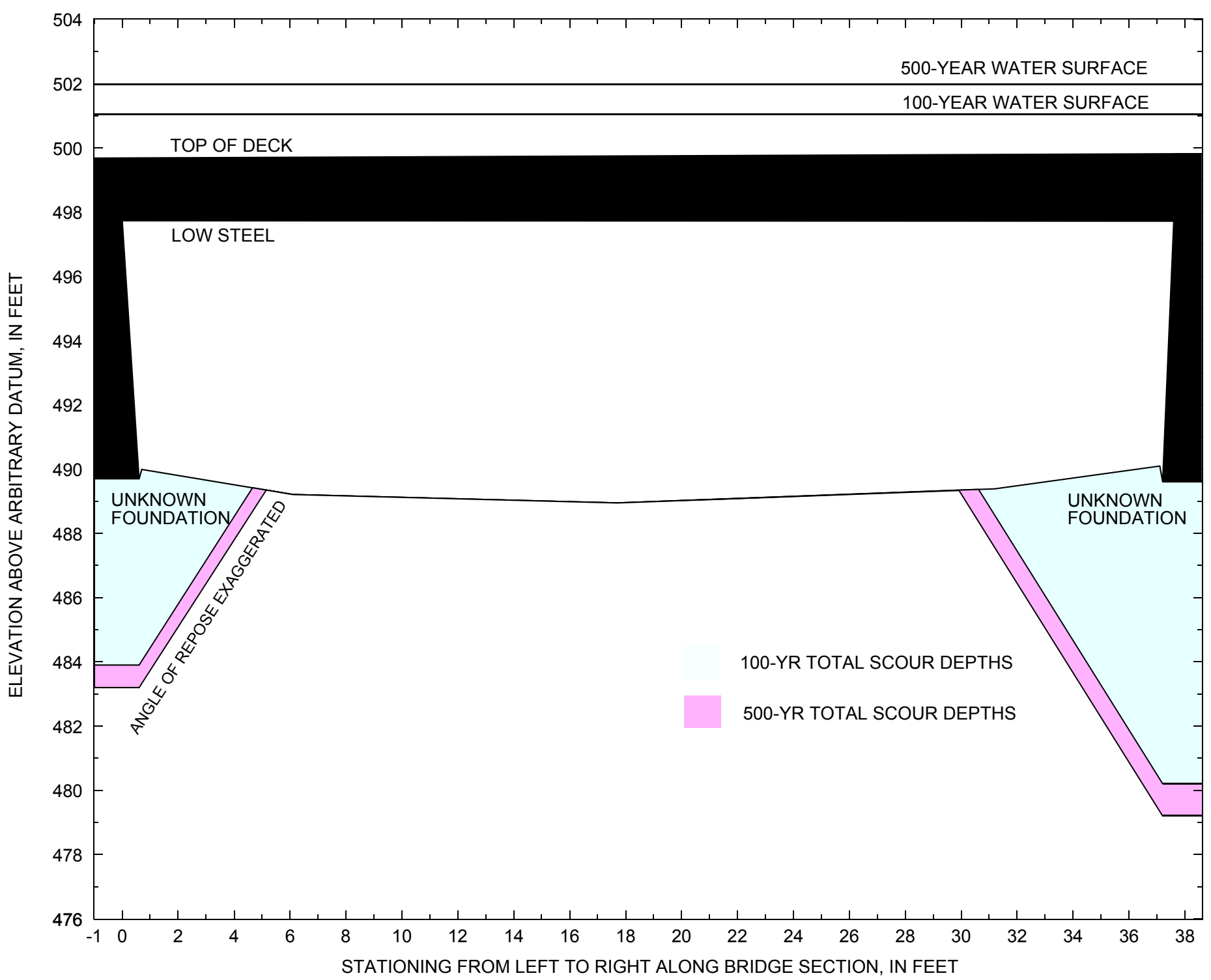

Figure 8. Scour elevations for the 100-year and 500-year discharges at structure CHESTH01180053 on Town Highway 118, crossing the Williams River, Chester, Vermont. 
Table 1. Remaining footing/pile depth at abutments for the 100-year discharge at structure CHESTH01180053 on Town Highway 118, crossing the Williams River, Chester, Vermont.

[VTAOT, Vermont Agency of Transportation; --,no data]

\begin{tabular}{|c|c|c|c|c|c|c|c|c|c|c|c|}
\hline Description & Station $^{1}$ & $\begin{array}{l}\text { VTAOT } \\
\text { minimum } \\
\text { low-chord } \\
\text { elevation } \\
\text { (feet) }\end{array}$ & $\begin{array}{c}\text { Surveyed } \\
\text { minimum } \\
\text { low-chord } \\
\text { elevation } \\
\text { (feet) }\end{array}$ & $\begin{array}{c}\text { Bottom of } \\
\text { footing/pile } \\
\text { elevation } \\
\text { (feet) }\end{array}$ & $\begin{array}{c}\text { Channel } \\
\text { elevation at } \\
\text { abutment/ } \\
\text { pier }^{2} \\
\text { (feet) }\end{array}$ & $\begin{array}{l}\text { Contraction } \\
\text { scour depth } \\
\text { (feet) }\end{array}$ & $\begin{array}{l}\text { Abutment } \\
\text { scour } \\
\text { depth } \\
\text { (feet) }\end{array}$ & $\begin{array}{l}\text { Pier } \\
\text { scour } \\
\text { depth } \\
\text { (feet) }\end{array}$ & $\begin{array}{l}\text { Depth of } \\
\text { total scour } \\
\text { (feet) }\end{array}$ & $\begin{array}{c}\text { Elevation of } \\
\text { scour }^{2} \\
\text { (feet) }\end{array}$ & $\begin{array}{c}\text { Remaining } \\
\text { footing/pile } \\
\text { depth } \\
\text { (feet) }\end{array}$ \\
\hline \multicolumn{12}{|c|}{100 -yr. discharge is 4,740 cubic-feet per second } \\
\hline Left abutment & 0.0 & -- & 497.7 & -- & 489.7 & 0.0 & 5.8 & -- & 5.8 & 483.9 & -- \\
\hline Right abutment & 37.6 & -- & 497.7 & -- & 489.6 & 0.0 & 9.4 & -- & 9.4 & 480.2 & -- \\
\hline
\end{tabular}

1.Measured along the face of the most constricting side of the bridge.

2.Arbitrary datum for this study.

Table 2. Remaining footing/pile depth at abutments for the 500-year discharge at structure CHESTH01180053 on Town Highway 118, crossing the Williams River, Chester, Vermont.

[VTAOT, Vermont Agency of Transportation; --, no data]

\begin{tabular}{|c|c|c|c|c|c|c|c|c|c|c|c|}
\hline Description & Station $^{1}$ & $\begin{array}{l}\text { VTAOT } \\
\text { minimum } \\
\text { low-chord } \\
\text { elevation } \\
\text { (feet) }\end{array}$ & $\begin{array}{c}\text { Surveyed } \\
\text { minimum } \\
\text { low-chord } \\
\text { elevation } \\
\text { (feet) }\end{array}$ & $\begin{array}{c}\text { Bottom of } \\
\text { footing/pile } \\
\text { elevation } \\
\text { (feet) }\end{array}$ & $\begin{array}{c}\text { Channel } \\
\text { elevation at } \\
\text { abutment/ } \\
\text { pier }^{2} \\
\text { (feet) }\end{array}$ & $\begin{array}{l}\text { Contraction } \\
\text { scour depth } \\
\text { (feet) }\end{array}$ & $\begin{array}{c}\text { Abutment } \\
\text { scour } \\
\text { depth } \\
\text { (feet) }\end{array}$ & $\begin{array}{l}\text { Pier } \\
\text { scour } \\
\text { depth } \\
\text { (feet) }\end{array}$ & $\begin{array}{l}\text { Depth of } \\
\text { total scour } \\
\text { (feet) }\end{array}$ & $\begin{array}{c}\text { Elevation of } \\
\text { scour }^{2} \\
\text { (feet) }\end{array}$ & $\begin{array}{c}\text { Remaining } \\
\text { footing/pile } \\
\text { depth } \\
\text { (feet) }\end{array}$ \\
\hline \multicolumn{12}{|c|}{500 -yr. discharge is 6,950 cubic-feet per second } \\
\hline Left abutment & 0.0 & -- & 497.7 & -- & 489.7 & 0.0 & 6.5 & -- & 6.5 & 483.2 & -- \\
\hline Right abutment & 37.6 & -- & 497.7 & -- & 489.6 & 0.0 & 10.4 & -- & 10.4 & 479.2 & -- \\
\hline
\end{tabular}

1.Measured along the face of the most constricting side of the bridge.

2.Arbitrary datum for this study. 


\section{SELECTED REFERENCES}

Arcement, G.J., Jr., and Schneider, V.R., 1989, Guide for selecting Manning's roughness coefficients for natural channels and flood plains:

U.S. Geological Survey Water-Supply Paper 2339, 38 p.

Barnes, H.H., Jr., 1967, Roughness characteristics of natural channels: U.S. Geological Survey Water-Supply Paper 1849,213 p.

Benson, M. A., 1962, Factors Influencing the Occurrence of Floods in a Humid Region of Diverse Terrain: U.S. Geological Survey WaterSupply Paper 1580-B, 64 p.

Brown, S.A. and Clyde, E.S., 1989, Design of riprap revetment: Federal Highway Administration Hydraulic Engineering Circular No. 11, Publication FHWA-IP-89-016, 156 p.

Federal Highway Administration, 1983, Runoff estimates for small watersheds and development of sound design: Federal Highway Administration Report FHWA-RD-77-158.

Federal Highway Administration, 1993, Stream Stability and Scour at Highway Bridges: Participant Workbook: Federal Highway Administration Report FHWA-HI-91-011.

Federal Emergency Management Agency, 1982, Flood Insurance Study, Town of Chester, Windsor County, Vermont: Washington, D.C., February 1982.

Froehlich, D.C., 1989, Local scour at bridge abutments in Ports, M.A., ed., Hydraulic Engineering--Proceedings of the 1989 National Conference on Hydraulic Engineering: New York, American Society of Civil Engineers, p. 13-18.

Hayes, D.C.,1993, Site selection and collection of bridge-scour data in Delaware, Maryland, and Virginia: U.S. Geological Survey WaterResources Investigation Report 93-4017, 23 p.

Interagency Advisory Committee on Water Data, 1982, Guidelines for determining flood flow frequency: U.S. Geological Survey, Bulletin 17B of the Hydrology Subcommittee, 190 p.

Johnson, C.G. and Tasker, G.D.,1974, Progress report on flood magnitude and frequency of Vermont streams: U.S. Geological Survey OpenFile Report 74-130, 37 p.

Lagasse, P.F., Schall, J.D., Johnson, F., Richardson, E.V., Chang, F., 1995, Stream Stability at Highway Structures: Federal Highway Administration Hydraulic Engineering Circular No. 20, Publication FHWA-IP-90-014, 144 p.

Laursen, E.M., 1960, Scour at bridge crossings: Journal of the Hydraulics Division, American Society of Civil Engineers, v. 86, no. HY2, p. 39-53.

Potter, W. D., 1957a, Peak rates of runoff in the Adirondack, White Mountains, and Maine woods area, Bureau of Public Roads

Potter, W. D., 1957b, Peak rates of runoff in the New England Hill and Lowland area, Bureau of Public Roads

Richardson, E.V. and Davis, S.R., 1995, Evaluating scour at bridges: Federal Highway Administration Hydraulic Engineering Circular No. 18, Publication FHWA-IP-90-017, 204 p.

Richardson, E.V., Simons, D.B., and Julien, P.Y., 1990, Highways in the river environment: Federal Highway Administration Publication FHWA-HI-90-016.

Ritter, D.F., 1984, Process Geomorphology: W.C. Brown Co., Debuque, Iowa, 603 p.

Shearman, J.O., 1990, User's manual for WSPRO--a computer model for water surface profile computations: Federal Highway Administration Publication FHWA-IP-89-027, 187 p.

Shearman, J.O., Kirby, W.H., Schneider, V.R., and Flippo, H.N., 1986, Bridge waterways analysis model; research report: Federal Highway Administration Publication FHWA-RD-86-108, 112 p.

Talbot, A.N., 1887, The determination of water-way for bridges and culverts.

U.S. Department of Transportation, 1993, Stream stability and scour at highway bridges, Participant Workbook: Federal Highway Administration Publication FHWA HI-91-011.

U.S. Geological Survey, 1972, Chester, Vermont 7.5 Minute Series quadrangle map: U.S. Geological Survey Topographic Maps, Scale $1: 24,000$. 


\section{APPENDIX A: \\ WSPRO INPUT FILE}




\section{WSPRO INPUT FILE}

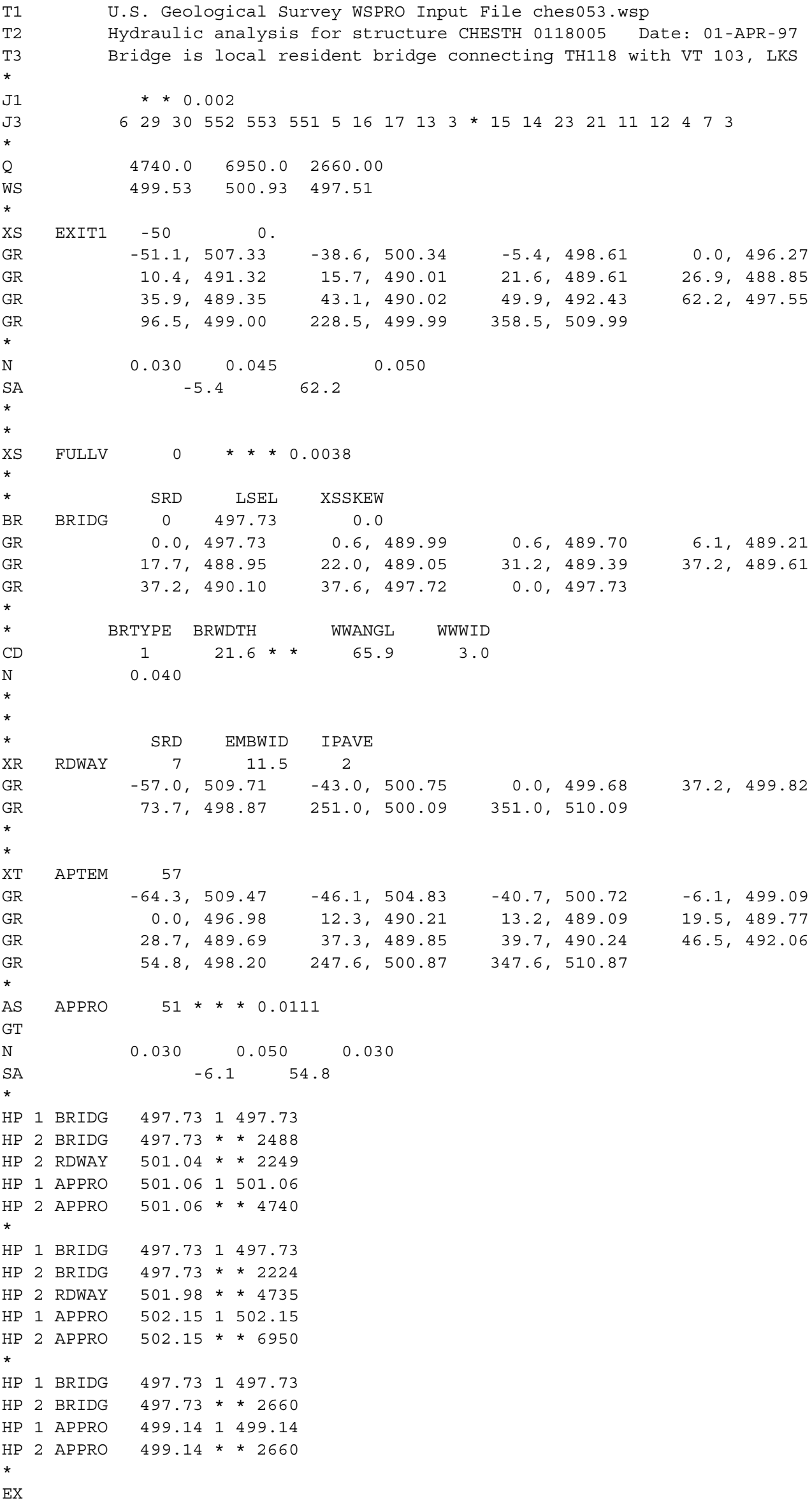




\section{APPENDIX B: \\ WSPRO OUTPUT FILE}




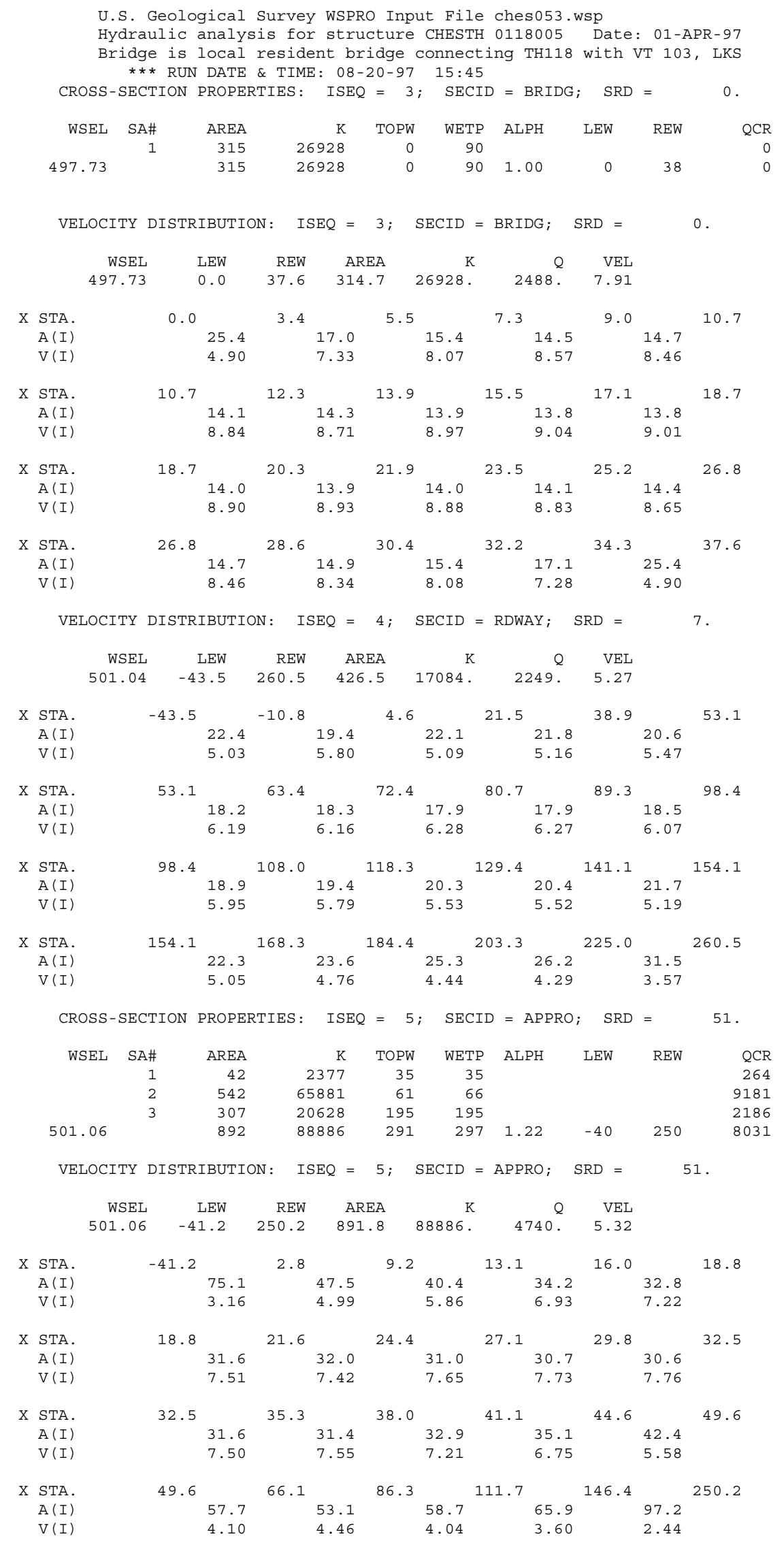


WSPRO OUTPUT FILE (continued)

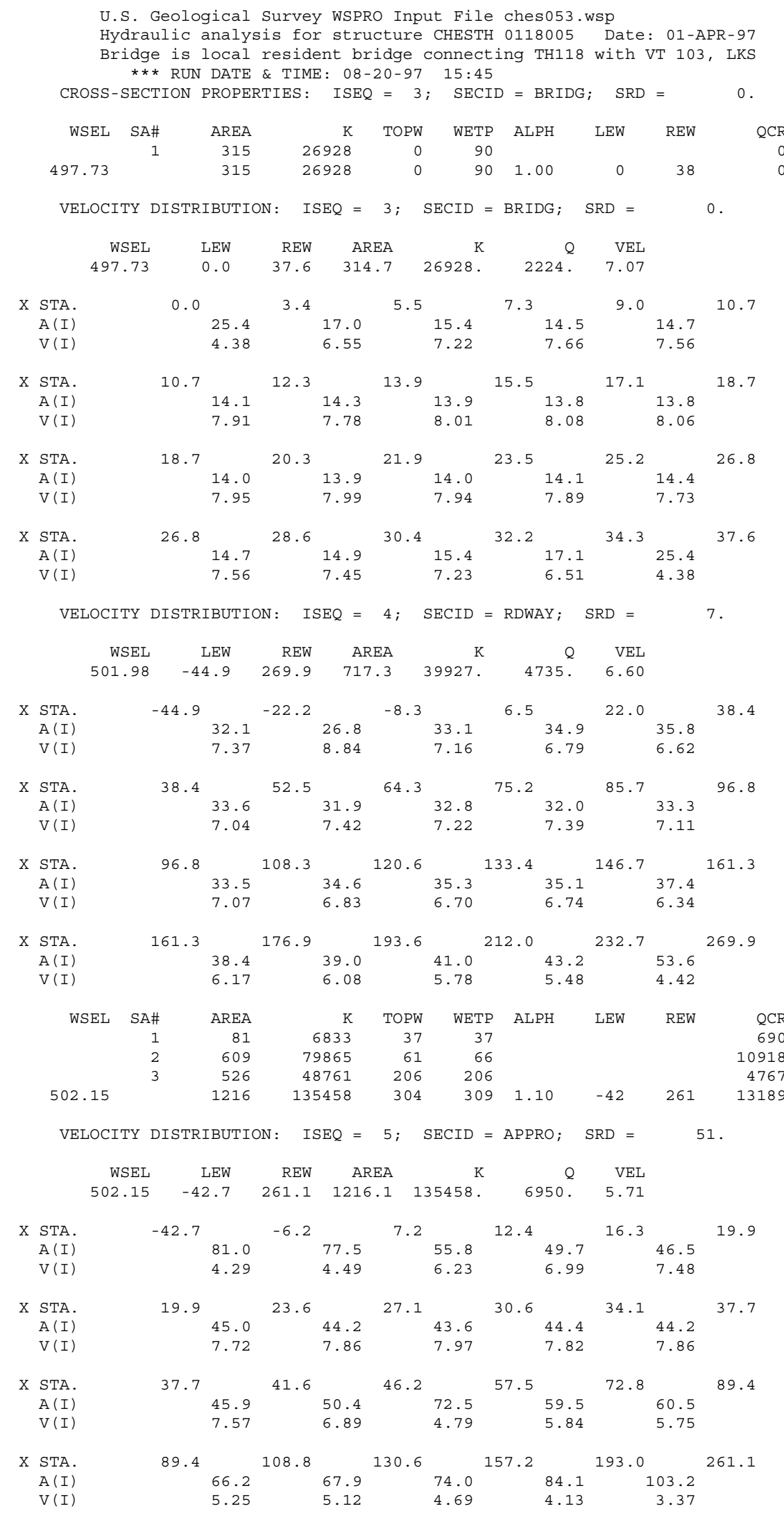


WSPRO OUTPUT FILE (continued)

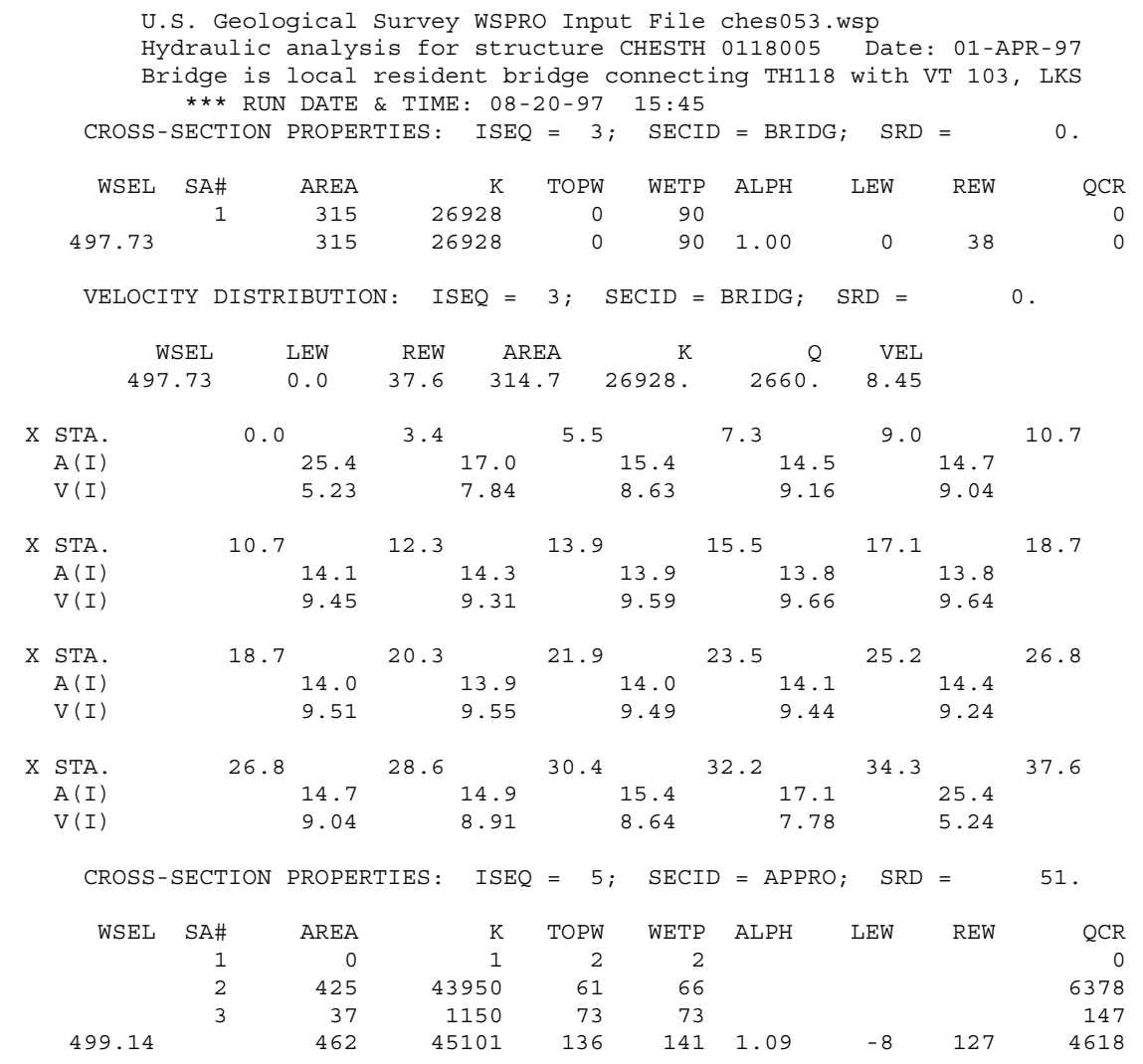

VELOCITY DISTRIBUTION : ISEQ $=5 ;$ SECID $=$ APPRO; $\quad$ SRD $=51$.

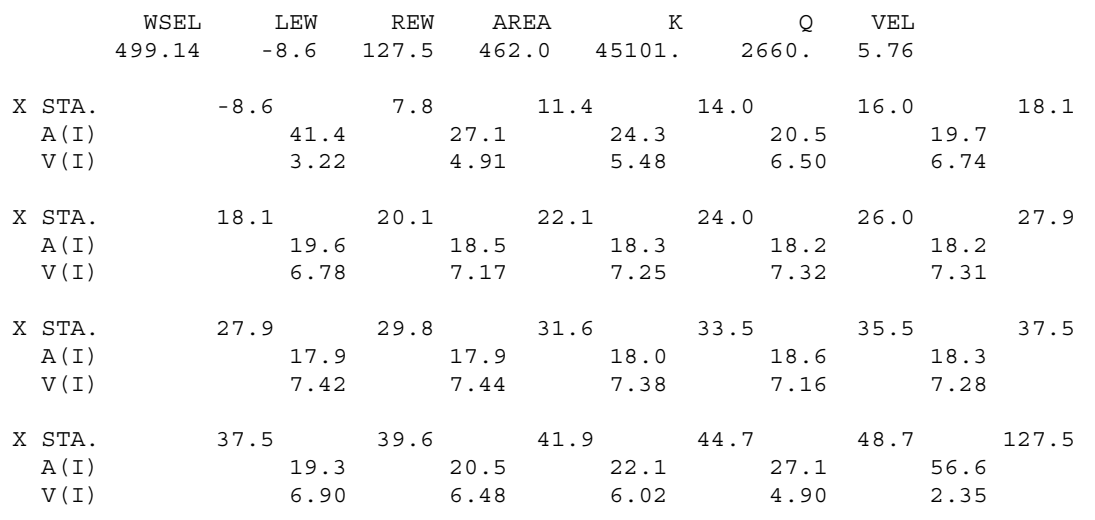


WSPRO OUTPUT FILE (continued)

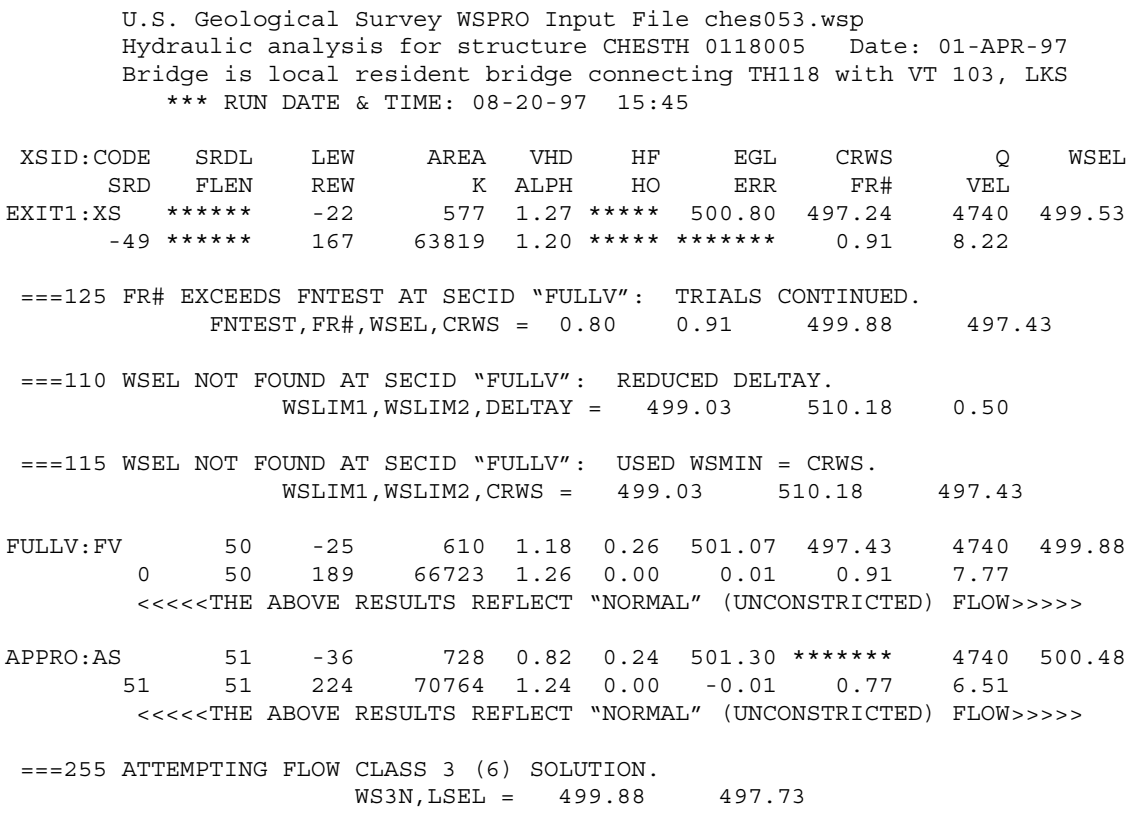

$\begin{array}{lcrrrrrrrr}\text { XSID : CODE } & \text { CRWS } & \text { FR\# } & \text { YMIN } & \text { YMAX } & \text { HF } & \text { HO } & \text { VHD } & \text { EGL } & \text { WSEL } \\ \text { EXIT1:XS } & 497.24 & 0.91 & 488.85 & 509.99 * * * * * * * * * * & 1.27 & 500.80 & 499.53 \\ \text { FULLV : FV } & 497.43 & 0.91 & 489.04 & 510.18 & 0.26 & 0.00 & 1.18 & 501.07 & 499.88 \\ \text { BRIDG : BR } & 494.46 & 0.48 & 488.95 & 497.73 * * * * * * * * * * & 0.97 & 498.70 & 497.73 \\ \text { RDWAY:RG } & * * * * * * * * * * * * * * * & 498.87 & 510.09 & 0.11 * * * * * * & 0.54 & 501.48 & 501.04 \\ \text { APPRO:AS } & 497.70 & 0.59 & 489.02 & 510.80 & 0.19 & 0.00 & 0.54 & 501.59 & 501.06\end{array}$


WSPRO OUTPUT FILE (continued)

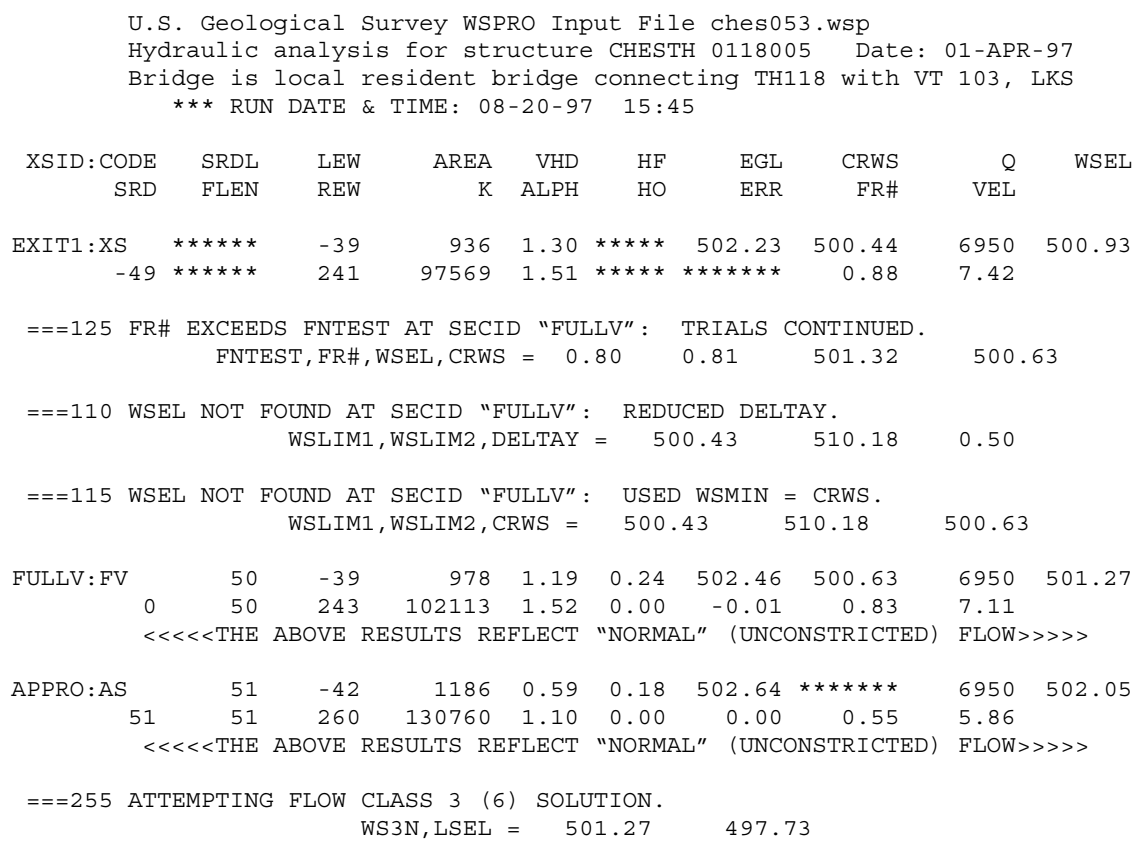


WSPRO OUTPUT FILE (continued)

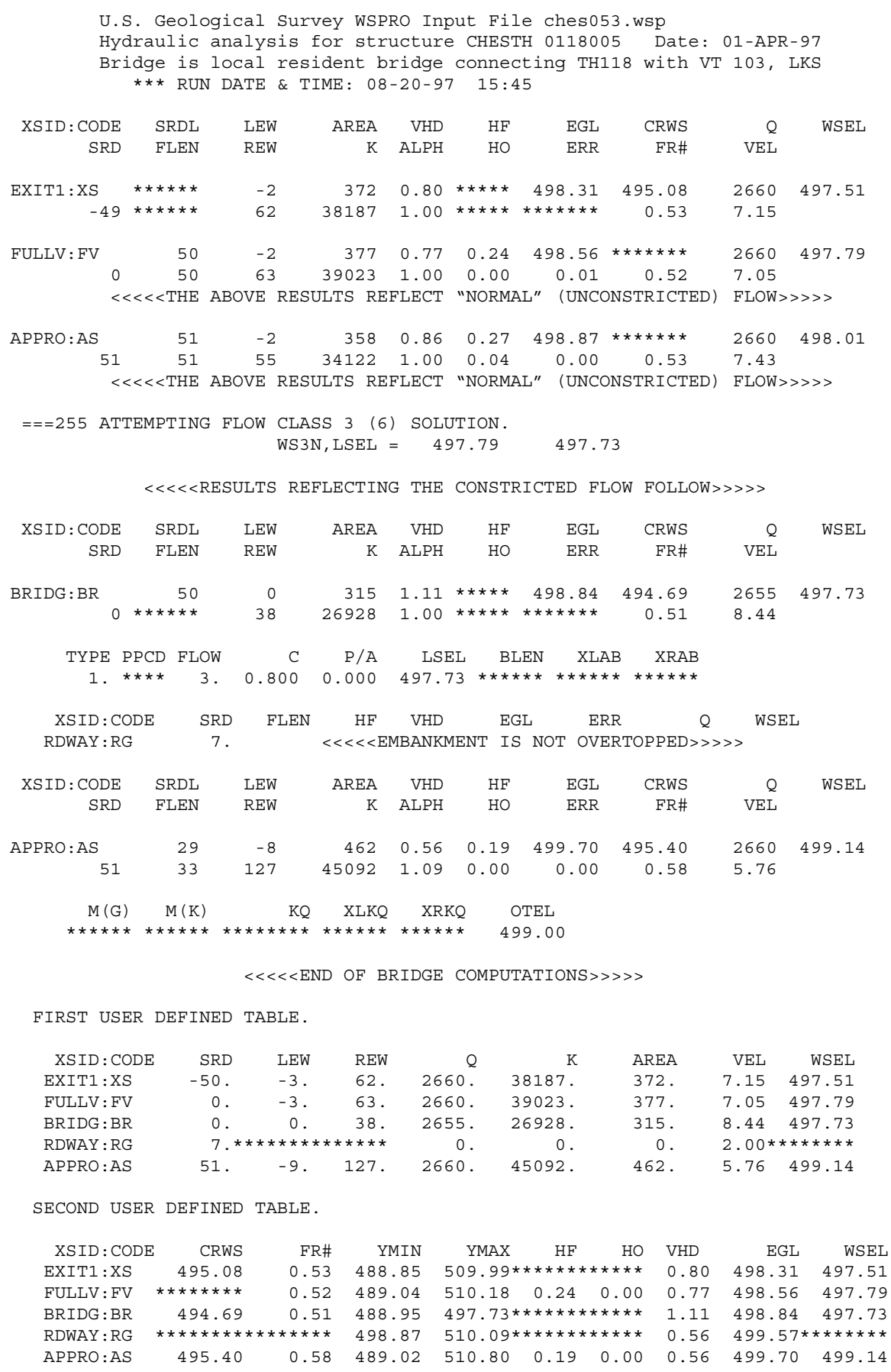




\section{APPENDIX C:}

\section{BED-MATERIAL PARTICLE-SIZE DISTRIBUTION}




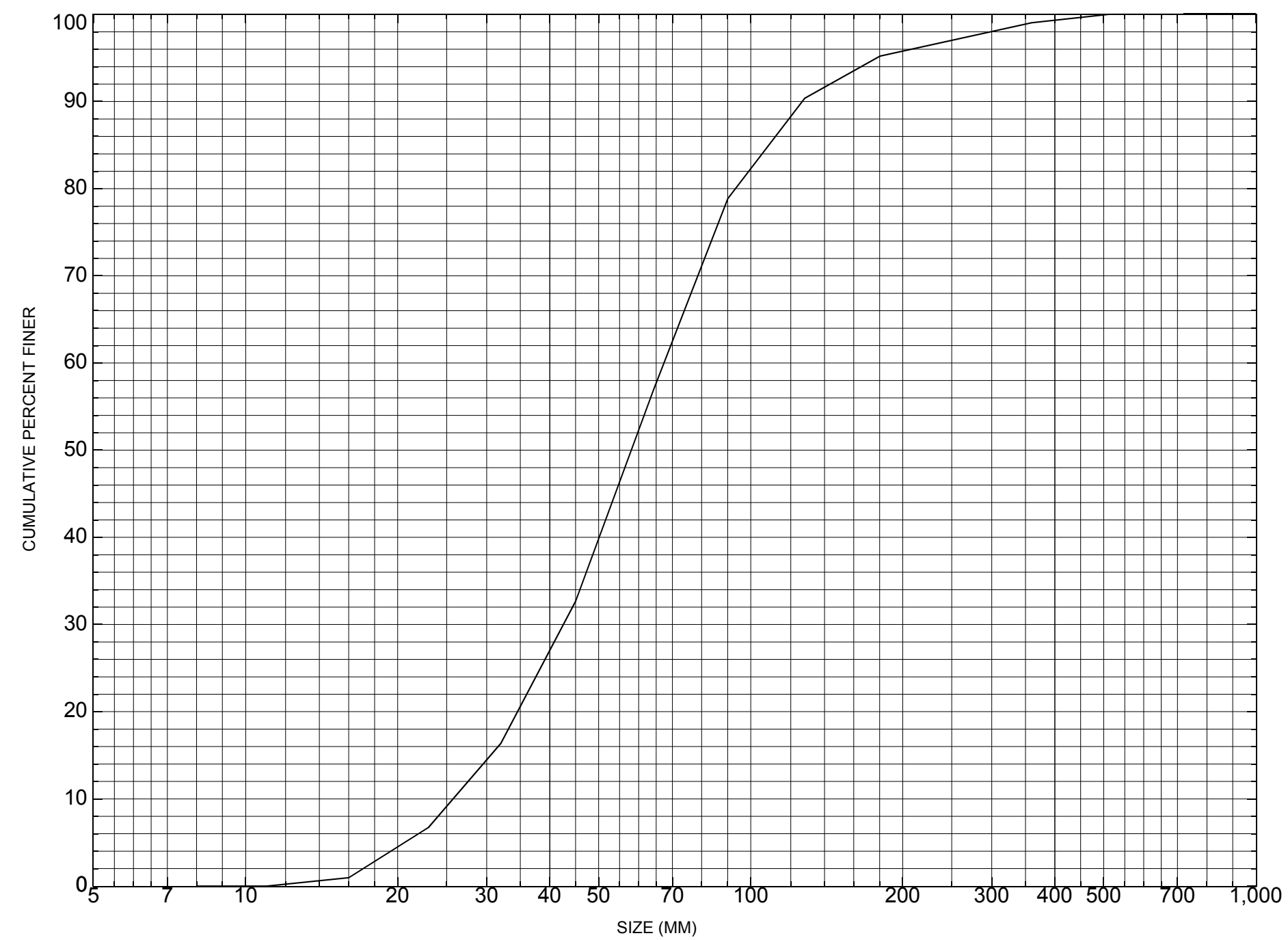

Appendix C. Bed material particle-size distribution for a pebble count in the channel approach of structure CHESTH01180053, in Chester, Vermont. 


\section{APPENDIX D: \\ HISTORICAL DATA FORM}




\section{Structure Number CHESTH01180053}

\section{General Location Descriptive}

Data collected by (First Initial, Full last name) M. IVANOFF

Date $(M M / D D / Y Y) \_\mathbf{0 4} / \underline{06} / \underline{95}$

Highway District Number (I - 2; nn) $\mathbf{0 2}$

Town (FIPS place code; I - 4; nnnnn) 13675

Waterway (I - 6) WILLIAMS RIVER

Route Number TH118

Topographic Map Chester

Latitude (I - 16; nnnn.n) $\mathbf{4 3 1 7 4}$
County (FIPS county code; I - 3; nnn)

Mile marker (I - 11; nnn.nnn) $\mathbf{3 0 0 0 0 0}$

Road Name (I - 7): -

Vicinity (I - 9) 0.01 MI TO JCT W VT103

Hydrologic Unit Code: $\mathbf{0 1 0 8 0 1 0 7}$

Longitude (i - 17; nnnnn.n) 72363

\section{Select Federal Inventory Codes}

FHWA Structure Number $(I$ - 8) $\mathbf{1 0 1 4 0 7 0 0 5 3 1 4 0 7}$

Maintenance responsibility $(I-21 ; n n) \quad \mathbf{0 3}$

Year built (I - 27; YYYY) 1919

Average daily traffic, ADT (I - 29; nnnnnn) 000020

Year of ADT (I - 30; YY) $\mathbf{9 4}$

Opening skew to Roadway $(I-34 ; n n) \quad \mathbf{0 0}$

Operational status $(I-41 ; X) \underline{\mathbf{A}}$

Structure type (I- 43; nnn) $\mathbf{3 0 2}$

Approach span structure type (I - 44; nnn) $\mathbf{0 0 0}$

Number of spans (I - 45; nnn) $\mathbf{0 0 1}$

Number of approach spans (I - 46; nnnn) 0000

Comments:

The structural inspection report of $09 / 23 / 95$ indicates the structure is a single span, steel beam type bridge with a concrete deck. Both concrete abutment faces have very minor stains noted. There is a section of footing in view at the upstream end of the right abutment. The streambed is flush with the top of the footing. The waterway has a fairly straight alignment through the structure. The streambed consists of stone and gravel with some random boulders.
Maximum span length (I - 48; nnnn) $\underline{0040}$

Structure length (I - 49; nnnnnn) $\underline{\mathbf{0 0 0 0 4 3}}$

Deck Width (I - 52; nn.n) 115

Channel \& Protection $(I-61 ; n) \underline{7}$

Waterway adequacy $(I-71 ; n) \underline{6}$

Underwater Inspection Frequency $(I-92 B ; X Y Y) \_$N

Year Reconstructed (I - 106) $\mathbf{0 0 0 0}$

Clear span (nnn.n ft) _

Vertical clearance from streambed (nnn.n ft) $\underline{\mathbf{8 . 0}}$

Waterway of full opening $\left(n n n . n \mathrm{ft}^{2}\right)$ 


\section{Bridge Hydrologic Data}

Is there hydrologic data available? $\underline{\mathbf{N}}$ if No, type ctrl-n $h \quad$ VTAOT Drainage area $\left(m i^{2}\right)$ : -

Terrain character:

Stream character \& type: -

Streambed material:

Discharge Data (cfs):

$$
\begin{aligned}
& Q_{2.33}- \\
& Q_{50}-
\end{aligned}
$$

Record flood date $(M M / D D / Y Y)$ :

Estimated Discharge (cfs): Ice conditions (Heavy, Moderate, Light) : -

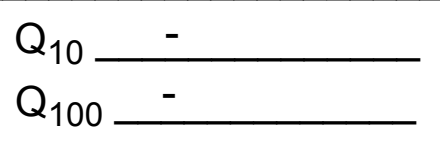

$$
\begin{aligned}
& Q_{25}- \\
& Q_{500}-
\end{aligned}
$$

Water surface elevation $(f t):-$ $(\mathrm{ft} / \mathrm{s}):$

The stage increases to maximum highwater elevation (Rapidly, Not rapidly):

The stream response is (Flashy, Not flashy):

Describe any significant site conditions upstream or downstream that may influence the stream's stage: -

Watershed storage area (in percent):

The watershed storage area is: - (1-mainly at the headwaters; 2- uniformly distributed; 3-immediatly upstream oi the site)

Water Surface Elevation Estimates for Existing Structure:

\begin{tabular}{|l|l|l|l|l|l|}
\hline Peak discharge frequency & $Q_{2.33}$ & $Q_{10}$ & $Q_{25}$ & $Q_{50}$ & $Q_{100}$ \\
Water surface elevation (ft)) & - & - & - & - & - \\
Velocity (ft/sec) & - & - & - & - & - \\
\hline
\end{tabular}

Long term stream bed changes: -

Is the roadway overtopped below the $\mathrm{Q}_{100}$ ? (Yes, No, Unknown): $\mathbf{U}$ Frequency: Relief Elevation (ft): Discharge over roadway at $Q_{100}\left(f^{3} / \mathrm{sec}\right)$ :

Are there other structures nearby? (Yes, No, Unknown): $\mathbf{Y}$ Upstream distance (miles): $\mathbf{0 . 2 5}$ Town: If No or Unknown, type ctrl-n os Highway No. : TH 17 Structure No. : 75 Structure Type: 302 Clear span (ft): $\underline{\mathbf{5 6 . 0}}$ Clear Height $(f t): \underline{\mathbf{1 2 . 0}}$ Full Waterway $\left(f t^{2}\right):$ 
Downstream distance (miles): $\mathbf{2 . 0}$ Town:

Chester Year Built:

Highway No. : VT 103 Structure No. : 12 Structure Type: 104

Clear span (ft): $\underline{\mathbf{8 7 . 0}}$ Clear Height $(f t): \underline{13.5}$ Full Waterway $\left(t^{2}\right): \underline{\mathbf{6 8 0 . 0}}$

Comments:

\section{USGS Watershed Data}

Watershed Hydrographic Data

Drainage area $(D A) \stackrel{20.82}{\mathrm{mi}^{2}}$

Lake/pond/swamp area

0.03 $\mathrm{mi}^{2}$

Watershed storage (ST) 0.1 $\%$

Bridge site elevation 640 $\mathrm{ft}$

Headwater elevation 2882 $\mathrm{ft}$

Main channel length 12.49 $\mathrm{mi}$ $10 \%$ channel length elevation $\mathbf{6 8 0}$ $\mathrm{ft} \quad 85 \%$ channel length elevation $\mathrm{ft}$

Main channel slope (S) 104.65 $\mathrm{ft} / \mathrm{mi}$

Watershed Precipitation Data

Average site precipitation in

Average headwater precipitation in

Maximum 2yr-24hr precipitation event $(124,2)$ in

Average seasonal snowfall (Sn) $\mathrm{ft}$ 


\section{Bridge Plan Data}

Are plans available? $\mathbf{N} \quad$ If no, type ctrl-n pl Date issued for construction (MM / YYYY):

Project Number

Minimum channel bed elevation:

Low superstructure elevation: USLAB DSLAB USRAB DSRAB Benchmark location description:

There is no benchmark information available.

Reference Point (MSL, Arbitrary, Other): Datum (NAD27, NAD83, Other):

Foundation Type: 4

If 1: Footing Thickness

If 2: Pile Type: (1-Wood; 2-S

(1-

(1-Spreadfooting; 2-Pile; 3- Gravity; 4-Unknown)

Footing bottom elevation:

If 3 : Footing bottom elevation:
Is boring information available?

Foundation Material Type: 3

Briefly describe material at foundation bottom elevation or around piles:

There is no foundation material information available.

Comments:

There are no bridge plans available. 


\section{Cross-sectional Data}

Is cross-sectional data available? Yes If no, type ctrl-n xs

Source (FEMA, VTAOT, Other)? FEMA

Comments: The measurements are in feet.

\begin{tabular}{|l|l|l|l|l|l|l|l|l|l|l|l|}
\hline Station & 217 & 234 & $\mathbf{2 5 5}$ & - & - & - & - & - & - & - & - \\
\hline Feature & LAB & & RAB & - & - & - & - & - & - & - & - \\
\hline $\begin{array}{l}\text { Low chord } \\
\text { elevation }\end{array}$ & $\mathbf{6 3 0 . 9}$ & $\mathbf{6 3 0 . 9}$ & $\mathbf{6 3 0 . 9}$ & - & - & - & - & - & - & - & - \\
\hline $\begin{array}{l}\text { Bed } \\
\text { elevation }\end{array}$ & $\mathbf{6 2 2 . 3}$ & $\mathbf{6 2 2 . 8}$ & $\mathbf{6 2 3 . 5}$ & - & - & - & - & - & - & - & - \\
\hline $\begin{array}{l}\text { Low chord- } \\
\text { bed }\end{array}$ & $\mathbf{8 . 6}$ & $\mathbf{8 . 1}$ & $\mathbf{7 . 4}$ & - & - & - & - & - & - & - & - \\
\hline Station & - & - & - & - & - & - & - & - & - & - & - \\
\hline Feature & - & - & - & - & - & - & - & - & - & - & - \\
\hline $\begin{array}{l}\text { Low chord } \\
\text { elevation }\end{array}$ & - & - & - & - & - & - & - & - & - & - & - \\
\hline $\begin{array}{l}\text { Bed } \\
\text { elevation }\end{array}$ & - & - & - & - & - & - & - & - & - & - & - \\
\hline $\begin{array}{l}\text { Low chord- } \\
\text { bed }\end{array}$ & - & - & - & - & - & - & - & - & - & - & - \\
\hline
\end{tabular}

Source (FEMA, VTAOT, Other)?

Comments: -

\begin{tabular}{|l|l|l|l|l|l|l|l|l|l|l|l|}
\hline Station & - & - & - & - & - & - & - & - & - & - & - \\
\hline Feature & - & - & - & - & - & - & - & - & - & - & - \\
\hline $\begin{array}{l}\text { Low chord } \\
\text { elevation }\end{array}$ & - & - & - & - & - & - & - & - & - & - & - \\
\hline $\begin{array}{l}\text { Bed } \\
\text { elevation }\end{array}$ & - & - & & - & - & - & - & - & - & - & - \\
\hline $\begin{array}{l}\text { Low chord- } \\
\text { bed }\end{array}$ & - & - & - & - & - & - & - & - & - & - & - \\
\hline Station & - & - & - & - & - & - & - & - & - & - & - \\
\hline Feature & - & - & - & - & - & - & - & - & - & - & - \\
\hline $\begin{array}{l}\text { Low chord } \\
\text { elevation }\end{array}$ & - & - & - & - & - & - & - & - & - & - & - \\
\hline $\begin{array}{l}\text { Bed } \\
\text { elevation }\end{array}$ & - & - & - & - & - & - & - & - & - & - & - \\
\hline $\begin{array}{l}\text { Low chord- } \\
\text { bed }\end{array}$ & - & - & - & - & - & - & - & - & - & - & - \\
\hline
\end{tabular}




\section{APPENDIX E: \\ LEVEL I DATA FORM}


U. S. Geological Survey

Bridge Field Data Collection and Processing Form

Qa/Qc Check by: $\underline{\mathbf{R B}}$ Date: 10/15/96

\section{Structure Number}

\section{A. General Location Descriptive}

1. Data collected by (First Initial, Full last name) L. MEDALIE

2. Highway District Number $\mathbf{0 2}$

County WINDSOR (027)

Waterway (I - 6) WILLIAMS RIVER

Route Number TH118
Date $(M M / D D / Y Y) \underline{09} / \underline{17} / \underline{1996}$

3. Descriptive comments:

Mile marker $\mathbf{3 0 0 0 0 0}$

Town CHESTER (13675)

Road Name -

Hydrologic Unit Code: $\mathbf{0 1 0 8 0 1 0 7}$

The bridge is located 0.01 miles from the junction of VT 103. A local resident stated that the bridge was not overtopped in the flood of 1973.

\section{B. Bridge Deck Observations}
4. Surface cover... LBUS 2
RBUS 4
LBDS 2
RBDS 2
Overall 2

(2b us, ds,lb,rb: 1- Urban; 2- Suburban; 3- Row crops; 4- Pasture; 5- Shrub- and brushland; 6- Forest; 7- Wetland)
5. Ambient water surface... US 1
UB 1
DS 1
(1- pool; 2- riffle)

6. Bridge structure type 1 (1- single span; 2- multiple span; 3- single arch; 4- multiple arch; 5-cylindrical culvert; 6- box culvert; or 7- other)
7. Bridge length 43
(feet)
Span length $\mathbf{4 0}$
(feet)
Bridge width 11.5 (feet)

\section{Road approach to bridge:}
8. LB 0
RB 1
( 0 even, 1- lower, 2- higher)
9. LB_2
RB $\underline{2}$
(1-Paved, 2- Not paved)

10. Embankment slope (run / rise in feet / foot)

US left

US right

\begin{tabular}{|c|c|c|c|}
\hline \multicolumn{2}{|c|}{ Protection } & \multirow{2}{*}{ 13.Erosion } & 14.Severity \\
\hline 11.Type & 12.Cond. & $\mathbf{0}$ & - \\
\hline $\mathbf{0}$ & - & $\mathbf{0}$ & $\mathbf{1}$ \\
\hline $\mathbf{0}$ & - & $\underline{\mathbf{2}}$ & - \\
\hline $\mathbf{0}$ & - & $\mathbf{0}$ & - \\
\hline $\mathbf{2}$ & $\mathbf{2}$ & $\mathbf{2}$ & $\mathbf{1}$ \\
\hline
\end{tabular}

Bank protection types: 0- none; 1- < 12 inches;

2- < 36 inches; 3- < 48 inches;

4- < 60 inches; 5- wall / artificial levee

Bank protection conditions: 1- good; 2- slumped;

3- eroded; 4- failed

Erosion: 0 - none; 1- channel erosion; 2 -

road wash; 3- both; 4- other

Erosion Severity: 0 - none; 1- slight; 2- moderate; 3- severe

\section{Channel approach to bridge (BF):}

15. Angle of approach: $\mathbf{0}$

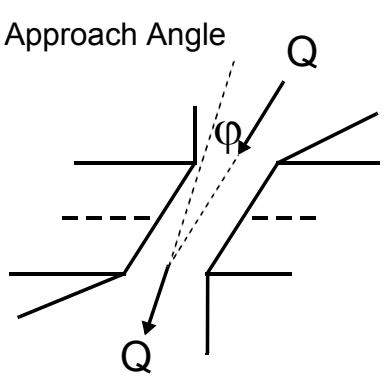

17. Channel impact zone 1 :

Where? LB (LB, RB)

Range? 78 feet US

Channel impact zone 2:

Where? $(L B, R B)$

Range? - $\quad$ feet -

(US, UB, DS) to feet Impact Severity: 0- none to very slight; 1- Slight; 2- Moderate; 3- Severe

16. Bridge skew: $\mathbf{5}$ Bridge Skew Angle

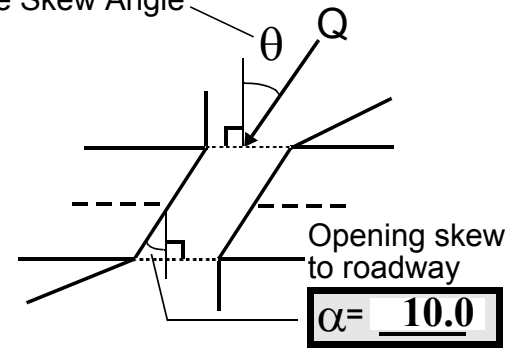

\section{Exist? $\mathbf{Y}(Y$ or $N)$}

Severity 1

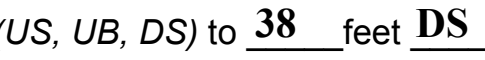

Exist? $\underline{\mathbf{N}}(\mathrm{Y}$ or $N)$

Severity - 
18. Bridge Type: 1a

1a- Vertical abutments with wingwalls

1 b- Vertical abutments without wingwalls

2- Vertical abutments and wingwalls, sloping embankment Wingwalls parallel to abut. face

3- Spill through abutments

4- Sloping embankment, vertical wingwalls and abutments

Wingwall angle less than $90^{\circ}$.

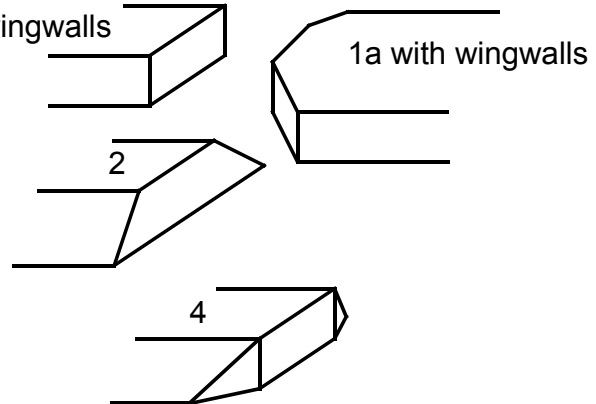

19. Bridge Deck Comments (surface cover variations, measured bridge and span lengths, bridge type variations, approach overflow width, etc.)

4. The right bank has trees along the bank and lawn beyond the trees and a house DS.

7. The bridge measurement values are from the VTAOT files. Measured bridge width is $11.6 \mathrm{ft}$., bridge span is $38 \mathrm{ft}$, and bridge length is $43 \mathrm{ft}$.

8. VT 103 is crowned so that the center of the road is slightly higher than the bridge and the sides of the road are slightly lower.

9. For the left road approach, there is a $5 \mathrm{ft}$ dirt section after the end of the bridge and then VT 103.

11. On the left bank DS there is a laid-up stone wall beyond the end of the wingwall that is slumped at the DS end. A small patch of asphalt was poured off the side of VT 103 with some loose gravel on both sides of it on the left bank DS for road wash drainage.

17. The most severe impact and greatest amount of protection is at $38 \mathrm{ft}$ US on the left bank.

\section{Upstream Channel Assessment}

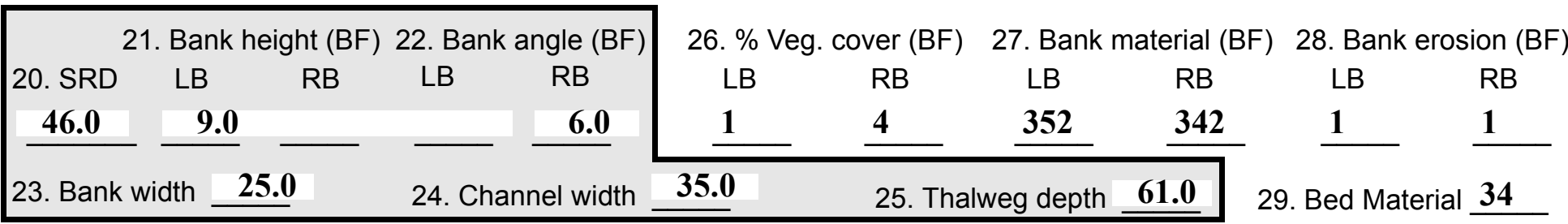

\section{0 .Bank protection type:}

LB $\underline{3}$

RB 0

31. Bank protection condition: LB 1

$\mathrm{RB}$ -

SRD - Section ref. dist. to US face \% Vegetation (Veg) cover: 1- 0 to 25\%; 2- 26 to 50\%; 3- 51 to $75 \%$; 4- 76 to $100 \%$

Bed and bank Material: 0- organics; 1- silt / clay, < 1/16mm; 2- sand, 1/16 - 2mm; 3- gravel, 2 - 64mm;

4- cobble, 64 - 256mm; 5- boulder, > 256mm; 6- bedrock; 7- manmade

Bank Erosion: 0- not evident; 1- light fluvial; 2- moderate fluvial; 3- heavy fluvial / mass wasting

Bank protection types: 0- absent; 1- < 12 inches; 2- < 36 inches; 3- < 48 inches; 4- < 60 inches; 5- wall / artificial levee

Bank protection conditions: 1-good; 2- slumped; 3- eroded; 4- failed

32. Comments (bank material variation, minor inflows, protection extent, etc.):

27. On the left bank, the boulders are added protection and not bank material because of VT 103 at the top of the bank.

30. The left bank protection is not continuous, but patchy. It is placed where needed from the US bridge face to $87 \mathrm{ft}$ US. 
33.Point/Side bar present? Y

36. Point bar extent: $\underline{\mathbf{4 5}}$ feet $\underline{\mathbf{U S}}$

$(Y$ or N. if $N$ type ctrl-n pb)34. Mid-bar distance: 66

35. Mid-bar width: $\mathbf{5}$

(US, UB) to $\mathbf{8 3}$ feet $\underline{\mathbf{U S}}$

(US, UB, DS) positioned 75

\%LB to $100 \%$ RB

37. Material: 34

38. Point or side bar comments (Circle Point or Side; Note additional bars, material variation, status, etc.):

39. Is a cut-bank present? $\mathbf{N}$ ( $Y$ or if $N$ type ctrl-n $c b)$

40. Where? - $(L B$ or $R B)$

41. Mid-bank distance: -

42. Cut bank extent: -

feet -

(US, UB) to feet (US, UB, DS)

43. Bank damage: -

(1- eroded and/or creep; 2- slip failure; 3- block failure)

44. Cut bank comments (eg. additional cut banks, protection condition, etc.):

There are no cut-banks upstream at this site.

45. Is channel scour present? $\mathbf{N}$ ( $Y$ or if $N$ type ctrl-n cs)

47. Scour dimensions: Length -

Width -

Depth : -

46. Mid-scour distance: -

48. Scour comments (eg. additional scour areas, local scouring process, etc.):

There is no channel scour upstream at this site. However, there is some very minor scour in the vicinity of a large boulder in the center of the channel at $90 \mathrm{ft}$ upstream.

49. Are there major confluences? $\mathbf{N}$

51. Confluence 1: Distance -

Confluence 2: Distance -

54. Confluence comments (eg. confluence name):

There are no major confluences upstream at this site.
(Y or if $N$ type ctrl-n mc)

52. Enters on -

Enters on ( $L B$ or $R B)$ (LB or $R B)$
50. How many? -

53. Type(1- perennial; 2- ephemeral)

Type (1-perennial; 2- ephemeral)

\section{Under Bridge Channel Assessment}

55. Channel restraint (BF)? LB 2

\begin{tabular}{|ccccc}
\hline \multicolumn{2}{|c}{ 56. Height (BF) } & \multicolumn{3}{c}{57 Angle (BF) } \\
LB & RB & LB & RB \\
34.0 & & & $\mathbf{0 . 5}$ & \\
\hline
\end{tabular}

58. Bank width (BF) (1- natural bank; 2- abutment; 3- artificial levee)

Bed and bank Material: 0- organics; 1- silt / clay, < 1/16mm; 2- sand, 1/16 - 2mm; 3- gravel, 2 - 64mm; 4- cobble, 64 - 256mm; 5- boulder, > 256mm; 6- bedrock; 7- manmade

61. Material (BF) 62. Erosion (BF)

LB RB LB RB

$\underline{2} \quad \underline{7} \quad \underline{-}$

60. Thalweg depth $\lcm{90.0}$

63. Bed Material -

Bank Erosion: 0- not evident; 1- light fluvial; 2- moderate fluvial; 3- heavy fluvial / mass wasting

64. Comments (bank material variation, minor inflows, protection extent, etc.):

3452

63. The bed material grades from sand and gravel at the left side of the channel, to cobbles in mid-channel, and back to gravel and sand at the right side of the channel. In addition to the sand and gravel there are a couple of random boulders. 
65. Debris and Ice Is there debris accumulation?

(Yor $N)$ 66. Where? $\mathbf{N}$

(1- Upstream; 2- At bridge; 3- Both)

67. Debris Potential (1-Low; 2- Moderate; 3- High)

68. Capture Efficiency 1 (1-Low; 2- Moderate; 3- High)

69. Is there evidence of ice build-up? 1 ( $Y$ or $N)$

Ice Blockage Potential $\underline{\mathbf{Y}}$

(1- Low; 2- Moderate; 3- High)

70. Debris and Ice Comments:

1

There is minor scraping of the bark on the US sides of the trees.

\begin{tabular}{|l|c|c|c|c|c|c|c|c|}
\hline Abutments & $\begin{array}{c}\text { 71. Attack } \\
\angle \text { (BF) }\end{array}$ & $\begin{array}{c}72 \text {. Slope } \angle \\
\text { (Qmax) }\end{array}$ & $\begin{array}{c}\text { 73. Toe } \\
\text { loc. (BF) }\end{array}$ & $\begin{array}{c}\text { 74. Scour } \\
\text { Condition }\end{array}$ & $\begin{array}{c}75 . \text { Scour } \\
\text { depth }\end{array}$ & $\begin{array}{c}\text { 76. Exposure } \\
\text { depth }\end{array}$ & 77. Material & 78. Length \\
\hline LABUT & & $\mathbf{5}$ & $\mathbf{9 0}$ & $\mathbf{2}$ & $\mathbf{1}$ & $\mathbf{0 . 5}$ & - & $\mathbf{9 0 . 0}$ \\
\hline RABUT & $\mathbf{1}$ & $\mathbf{0}$ & $\mathbf{9 0}$ & & & $\mathbf{2}$ & $\mathbf{2}$ & $\mathbf{3 7 . 0}$ \\
\hline
\end{tabular}

Pushed: $L B$ or RB

Toe Location (Loc.): 0- even, 1- set back, 2- protrudes

Scour cond.: 0- not evident; 1- evident (comment); 2- footing exposed; 3-undermined footing; 4- piling exposed; 5- settled; 6- failed

Materials: 1- Concrete; 2- Stone masonry or drywall; 3- steel or metal; 4- wood

79. Abutment comments (eg. undermined penetration, unusual scour processes, debris, etc.):

0.5

0.5

1

74. There is a small scour hole near the left abutment under the bridge that is $9 \mathrm{ft}$ long and $4 \mathrm{ft}$ wide.

76. The right abutment footing is exposed $0.5 \mathrm{ft}$ at the US end. There is also a $1.5 \mathrm{ft}$ square chunk eroded from the bottom DS end of the right abutment.

75. A minor $2 \mathrm{ft}$ round scour hole is in the sand at the corner of the US right wingwall and right abutment.

80. Wingwalls:

Exist? Material? Scour Scour Exposure $\begin{aligned} & 81 . \\ & \text { Angle? Length? }\end{aligned}$ Condition? depth? depth?

USLWW:

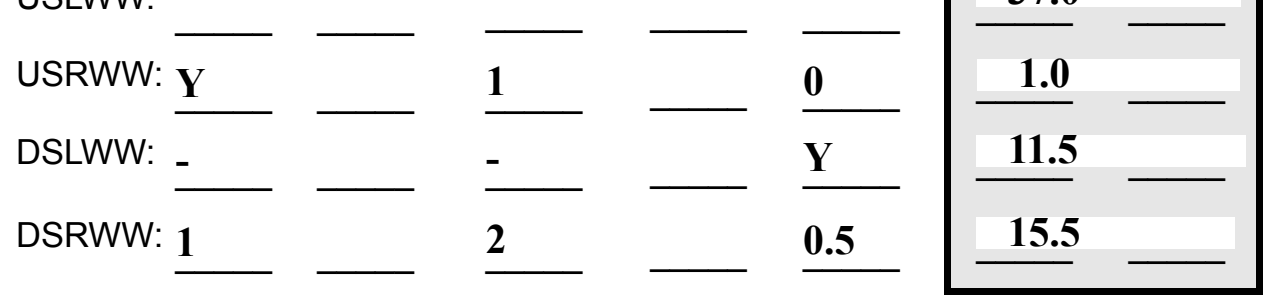

Wingwall materials: 1- Concrete; 2- Stone masonry or drywall; 3- steel or metal; 4- wood

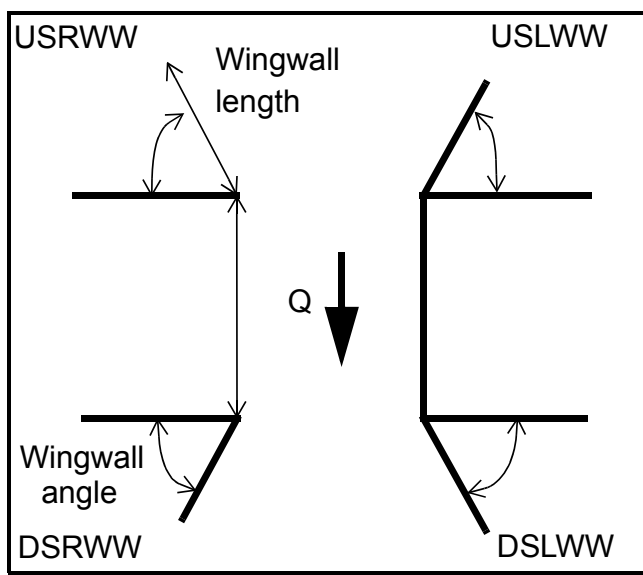

82. Bank / Bridge Protection:

\begin{tabular}{|l|l|l|l|l|l|l|l|l|}
\hline Location & USLWW & USRWW & LABUT & RABUT & LB & RB & DSLWW & DSRWW \\
\hline Type & $\mathbf{0 . 5}$ & $\mathbf{0}$ & $\mathbf{N}$ & - & $\mathbf{1}$ & - & $\mathbf{2}$ & - \\
\hline Condition & $\mathbf{Y}$ & - & - & - & $\mathbf{1}$ & - & $\mathbf{2}$ & - \\
\hline Extent & $\mathbf{1}$ & - & - & $\mathbf{2}$ & $\mathbf{0}$ & $\mathbf{2}$ & $\mathbf{0}$ & - \\
\hline
\end{tabular}

Bank / Bridge protection types: 0- absent; 1- < 12 inches; 2- < 36 inches; 3- < 48 inches; 4- < 60 inches; 
83. Wingwall and protection comments (eg. undermined penetration, unusual scour processes, etc.):

-
-
-
-
-
2
2
2
-
-
-

\section{Piers:}

84. Are there piers? 80. (Y or if $N$ type ctrl-n pr)

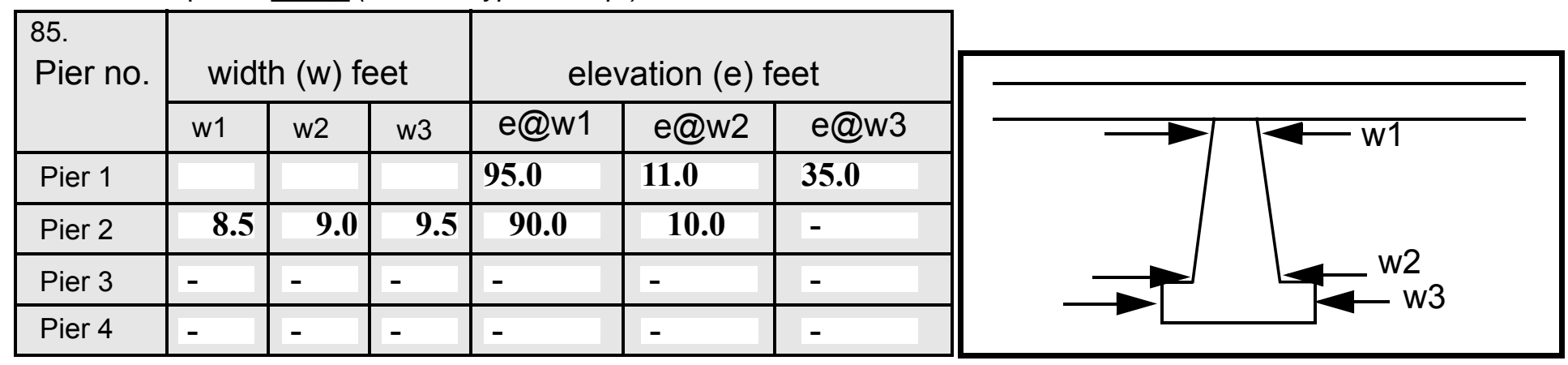

\begin{tabular}{|l|l|l|l|l|}
\hline Level 1 Pier Descr. & \multicolumn{1}{|c|}{1} & \multicolumn{1}{|c|}{2} & \multicolumn{1}{|c|}{3} & \multicolumn{1}{|c|}{4} \\
\hline 86. Location (BF) & The & then & the & at the \\
\hline 87. Type & DS & turn & end. & DS \\
\hline 88. Material & left & s & The & end. \\
\hline 89. Shape & wing & into & US & The \\
\hline 90. Inclined? & wall & a & right & US \\
\hline 91. Attack $\angle$ (BF) & is & stone & wing & right \\
\hline 92. Pushed & con- & wall & wall & wing \\
\hline 93. Length (feet) & - & - & - & - \\
\hline 94. \# of piles & crete & that & foot- & wall \\
\hline 95. Cross-members & for & is & ing is & exte \\
\hline 96. Scour Condition & the & slum & only & nds \\
\hline 97. Scour depth & first & ped & expo & out \\
\hline 98. Exposure depth & $\mathbf{7 ~ f t ~}$ & at & sed & from \\
\hline
\end{tabular}

LFP, LTB, LB, MCL, MCM, MCR, RB, RTB, RFP

1- Solid pier, 2-column, 3- bent

1-Wood; 2- concrete; 3- metal; 4- stone

1- Round; 2- Square; 3- Pointed

Y-yes; $N-$ no

$L B$ or $R B$

0- none; 1- laterals; 2- diagonals; 3- both

0- not evident; 1- evident (comment);

2- footing exposed; 3- piling exposed;

4- undermined footing; 5- settled; 6- failed 
99. Pier comments (eg. undermined penetration, protection and protection extent, unusual scour processes, etc.):

the edge of the abutment $6.3 \mathrm{ft}$ and then angles back for an additional $2 \mathrm{ft}$. At this point there are remains of a slumping stone wall for $5 \mathrm{ft}$.

$\mathbf{N}$

100.

\section{E. Downstream Channel Assessment}

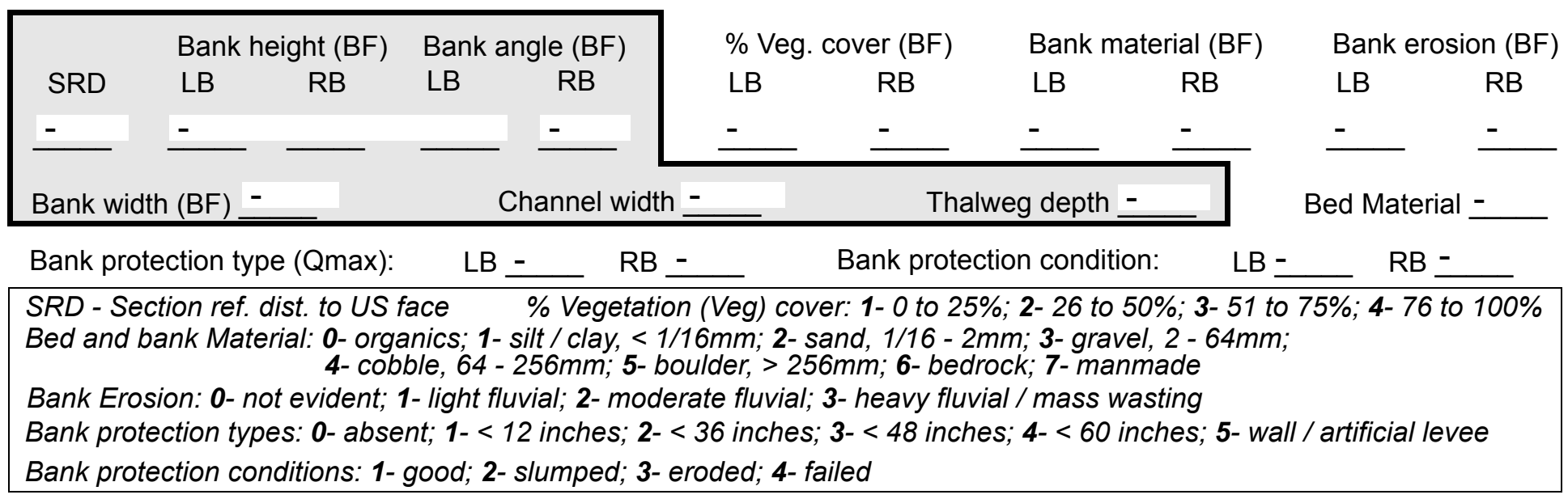

Comments (eg. bank material variation, minor inflows, protection extent, etc.):

-

$-$

$-$

$-$

$-$

$-$

$-$

$-$

$-$

$-$

$-$

$-$

$-$

$-$

$-$

101. Is a drop structure present? _ ( $Y$ or $N$, if $N$ type ctrl-n ds) 102. Distance: ___ feet 103. Drop: __ feet 104. Structure material: ___ (1- steel sheet pile; 2- wood pile; 3- concrete; 4- other) 105. Drop structure comments (eg. downstream scour depth):

$-$

$-$

$-$

$-$ 
106. Point/Side bar present? (Y or $N$. if $N$ type ctrl-n pb)Mid-bar distance:

Mid-bar width: -

Point bar extent: feet (US, UB, DS) to feet (US, UB, DS) positioned \%LB to $\% \mathrm{RB}$ Material:

Point or side bar comments (Circle Point or Side), note additional bars, material variation, status, etc.):

S a cut-bank present? Th (Y or if $N$ type ctrl- $n c b) \quad$ Where? ere (LB or RB) Mid-bank distance: are

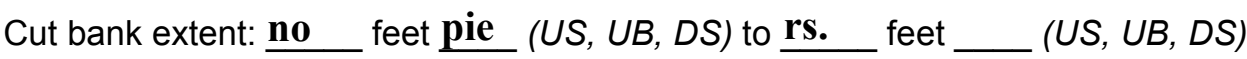

Bank damage: (1- eroded and/or creep; 2- slip failure; 3- block failure)

Cut bank comments (eg. additional cut banks, protection condition, etc.):

Is channel scour present? ( $Y$ or if $N$ type ctrl-n cs)

Mid-scour distance: Scour dimensions: Length Width Depth: 3

Positioned $\underline{54} \%$ LB to $24 \%$ RB Scour comments (eg. additional scour areas, local scouring process, etc.): 1 0 345 3

Are there major confluences? $\mathbf{0}$ ( $Y$ or if $N$ type ctrl-n $m c)$ How many? 1 Confluence 1: Distance Enters on The ( $L B$ or RB) Type left (1-perennial; 2- ephemeral) Confluence 2: Distance bank Enters on pro- $(L B$ or $R B)$ Type tec(1- perennial; 2- ephemeral) Confluence comments (eg. confluence name):

tion is a few large boulders in the bank from the end of the wingwall to $35 \mathrm{ft}$ DS.

\section{F. Geomorphic Channel Assessment}

107. Stage of reach evolution

1- Constructed

2- Stable

3- Aggraded

4- Degraded

5- Laterally unstable

6- Vertically and laterally unstable 
108. Evolution comments (Channel evolution not considering bridge effects; See HEC-20, Figure 1 for geomorphic descriptors): 


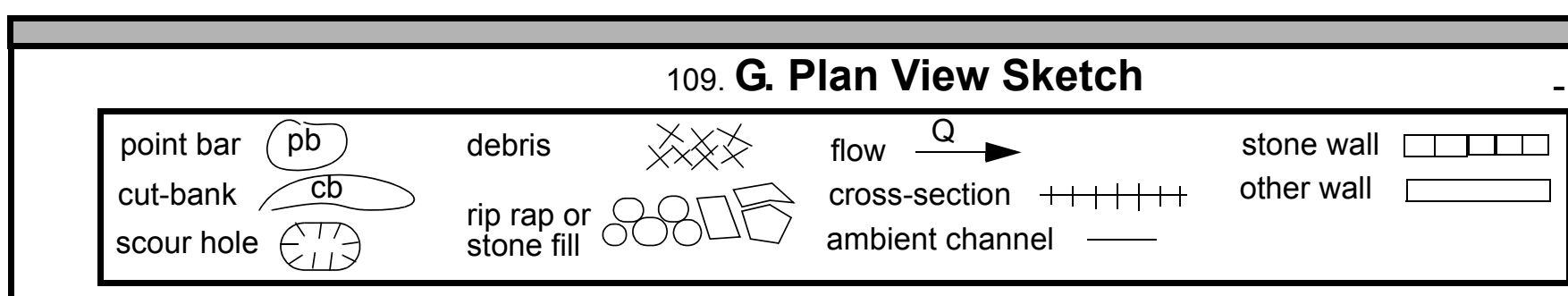


APPENDIX F:

SCOUR COMPUTATIONS 
SCOUR COMPUTATIONS

\begin{tabular}{|c|c|c|c|}
\hline Structure Number: CHESTH01180053 & & Town: & CHESTER \\
\hline Road Number: $\quad$ TH 118 & & County: & WINDSOR \\
\hline WILLIAMS RIVER & & & \\
\hline Initials LKS & Checked: & EMB & \\
\hline Analysis of contraction scour, live & -bed or $\mathrm{C}$ & lear wat & \\
\hline $\begin{array}{l}\text { Critical Velocity of Bed Material } \\
\mathrm{VC}=11.21^{*} \mathrm{y} 1^{\wedge} 0.1667 * \mathrm{D} 50^{\wedge} 0.33 \text { with } \mathrm{S}\end{array}$ & $\begin{array}{l}\text { converted } \\
=2.65\end{array}$ & to Engl & sh units) \\
\hline pproach Section & & & \\
\hline Characteristic & $100 \mathrm{yr}$ & $500 \mathrm{yr}$ & other $Q$ \\
\hline Total discharge, cfs & 4740 & 6950 & 2660 \\
\hline Main Channel Area, ft2 & 542 & 609 & 425 \\
\hline Left overbank area, ft2 & 42 & 81 & 0 \\
\hline Right overbank area, ft2 & 307 & 526 & 37 \\
\hline Top width main channel, ft & 61 & 61 & 61 \\
\hline Top width L overbank, ft & 35 & 37 & 2 \\
\hline Top width $\mathrm{R}$ overbank, ft & 195 & 206 & 73 \\
\hline D50 of channel, ft & 0.1903 & 0.1903 & 0.1903 \\
\hline D50 left overbank, ft & -- & -- & -- \\
\hline D50 right overbank, ft & -- & -- & -- \\
\hline y1, average depth, $M C$, ft & 8.9 & 10.0 & 7.0 \\
\hline y1, average depth, LOB, ft & 1.2 & 2.2 & 0.0 \\
\hline Y1, average depth, ROB, ft & 1.6 & 2.6 & 0.5 \\
\hline Total conveyance, approach & 88886 & 135458 & 45101 \\
\hline Conveyance, main channel & 65881 & 79865 & 43950 \\
\hline Conveyance, LOB & 2377 & 6833 & 1 \\
\hline Conveyance, ROB & 20628 & 48761 & 1150 \\
\hline Percent discrepancy, conveyance & 0.0000 & -0.0007 & 0.0000 \\
\hline Qm, discharge, MC, cfs & 3513.2 & 4097.7 & 2592.1 \\
\hline Q1, discharge, LOB, cfs & 126.8 & 350.6 & 0.1 \\
\hline Qr, discharge, ROB, cfs & 1100.0 & 2501.8 & 67.8 \\
\hline Vm, mean velocity $M C$, ft/s & 6.5 & 6.7 & 6.1 \\
\hline VI, mean velocity, LOB, ft/s & 3.0 & 4.3 & ERR \\
\hline Vr, mean velocity, ROB, ft/s & 3.6 & 4.8 & 1.8 \\
\hline Vc-m, crit. velocity, $M C$, ft/s & 9.3 & 9.5 & 8.9 \\
\hline Vc-l, crit. velocity, LOB, ft/s & ERR & ERR & ERR \\
\hline Vc-r, crit. velocity, ROB, ft/s & ERR & ERR & ERR \\
\hline Results & & & \\
\hline Live-bed(1) or Clear-Water(0) Contr & action $\mathrm{Sc}$ & our? & \\
\hline Main Channel & 0 & 0 & 0 \\
\hline Left Overbank & $\mathrm{N} / \mathrm{A}$ & $\mathrm{N} / \mathrm{A}$ & $\mathrm{N} / \mathrm{A}$ \\
\hline Right Overbank & $\mathrm{N} / \mathrm{A}$ & $\mathrm{N} / \mathrm{A}$ & $\mathrm{N} / \mathrm{A}$ \\
\hline
\end{tabular}


Clear water Contraction Scour in MAIN CHANNEL

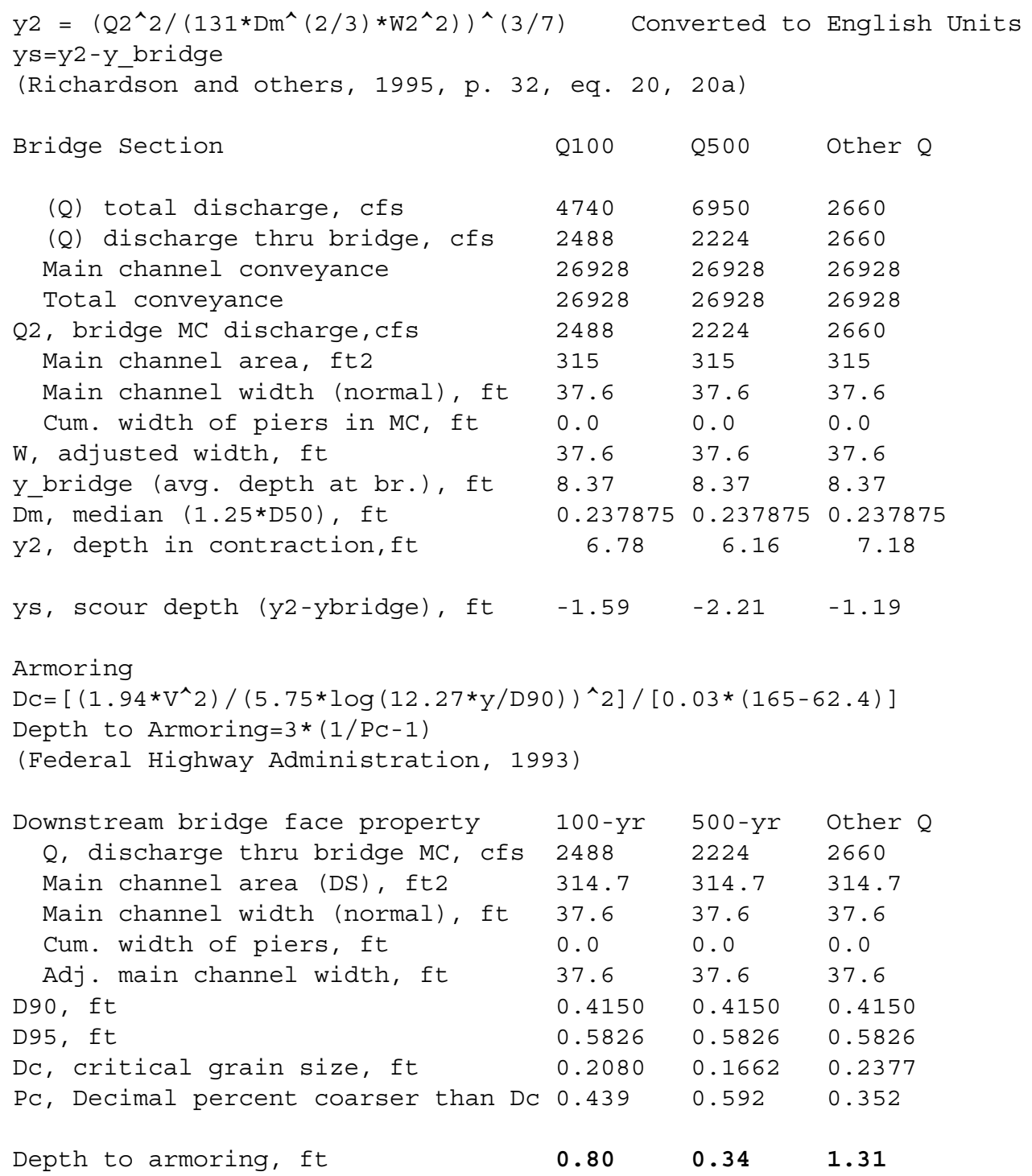




\begin{tabular}{|c|c|c|c|c|}
\hline \multicolumn{5}{|c|}{$\begin{array}{l}\text { Umbrell pressure flow equation } \\
(\mathrm{Hb}+\mathrm{Ys}) / \mathrm{ya}=1.1021 *[(1-\mathrm{w} / \mathrm{ya}) *(\mathrm{Va} / \mathrm{VC})]^{\wedge} 0.6031 \\
\text { (Richardson and other, 1995, p. 144-146) }\end{array}$} \\
\hline & Q100 & Q500 & OtherQ & \\
\hline Q, total, cfs & 4740 & 6950 & 2660 & \\
\hline Q, thru bridge $M C$, cfs & 2488 & 2224 & 2660 & \\
\hline Vc, critical velocity, ft/s & 9.28 & 9.46 & 8.91 & \\
\hline Va, velocity MC approach, ft/s & 6.48 & 6.73 & 6.10 & \\
\hline Main channel width (normal), ft & 37.6 & 37.6 & 37.6 & \\
\hline Cum. width of piers in MC, ft & 0.0 & 0.0 & 0.0 & \\
\hline W, adjusted width, ft & 37.6 & 37.6 & 37.6 & \\
\hline qbr, unit discharge, ft2/s & 66.2 & 59.1 & 70.7 & \\
\hline Area of full opening, ft2 & 314.7 & 314.7 & 314.7 & \\
\hline $\mathrm{Hb}$, depth of full opening, ft & 8.37 & 8.37 & 8.37 & \\
\hline Fr, Froude number, bridge MC & 0.48 & 0.43 & 0.51 & \\
\hline Cf, Fr correction factor $(<=1.0)$ & 1.00 & 1.00 & 1.00 & \\
\hline **Area at downstream face, ft2 & $\mathrm{N} / \mathrm{A}$ & $\mathrm{N} / \mathrm{A}$ & $\mathrm{N} / \mathrm{A}$ & \\
\hline **Hb, depth at downstream face, ft & $\mathrm{N} / \mathrm{A}$ & $\mathrm{N} / \mathrm{A}$ & $\mathrm{N} / \mathrm{A}$ & \\
\hline **Fr, Froude number at DS face & $\mathrm{ERR}$ & ERR & $\mathrm{ERR}$ & \\
\hline$* * \mathrm{Cf}$, for downstream face $(<=1.0)$ & $\mathrm{N} / \mathrm{A}$ & $\mathrm{N} / \mathrm{A}$ & $\mathrm{N} / \mathrm{A}$ & \\
\hline Elevation of Low steel, ft & 497.73 & 497.73 & 497.73 & \\
\hline Elevation of Bed, ft & 489.36 & 489.36 & 489.36 & \\
\hline Elevation of Approach, ft & 501.06 & 502.15 & 499.14 & \\
\hline Friction loss, approach, ft & 0.19 & 0.23 & 0.19 & \\
\hline Elevation of WS immediately US, ft & 500.87 & 501.92 & 498.95 & \\
\hline ya, depth immediately US, ft & 11.51 & 12.56 & 9.59 & \\
\hline Mean elevation of deck, ft & 499.75 & 499.75 & 499.75 & \\
\hline w, depth of overflow, ft $(>=0)$ & 1.12 & 2.17 & 0.00 & \\
\hline Cc, vert contrac correction $(<=1.0)$ & 0.95 & 0.95 & 0.97 & \\
\hline$* * C c$, for downstream face $(<=1.0)$ & ERR & ERR & ERR & \\
\hline Ys, scour w/Chang equation, ft & -0.84 & -1.77 & -0.16 & \\
\hline Ys, scour w/Umbrell equation, ft & 1.24 & 1.68 & 0.04 & \\
\hline
\end{tabular}




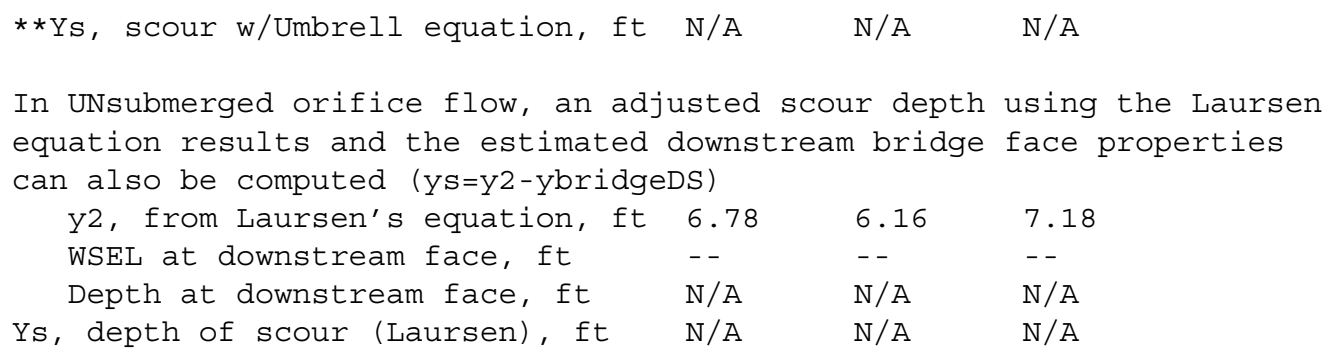

Abutment scour

Froehlich's Abutment Scour

$\mathrm{Ys} / \mathrm{Y} 1=2.27 * \mathrm{~K} 1 * \mathrm{~K} 2 *\left(\mathrm{a}^{\prime} / \mathrm{Y} 1\right)^{\wedge} 0.43 * \mathrm{Fr} 1^{\wedge} 0.61+1$

(Richardson and others, 1995, p. 48, eq. 28)

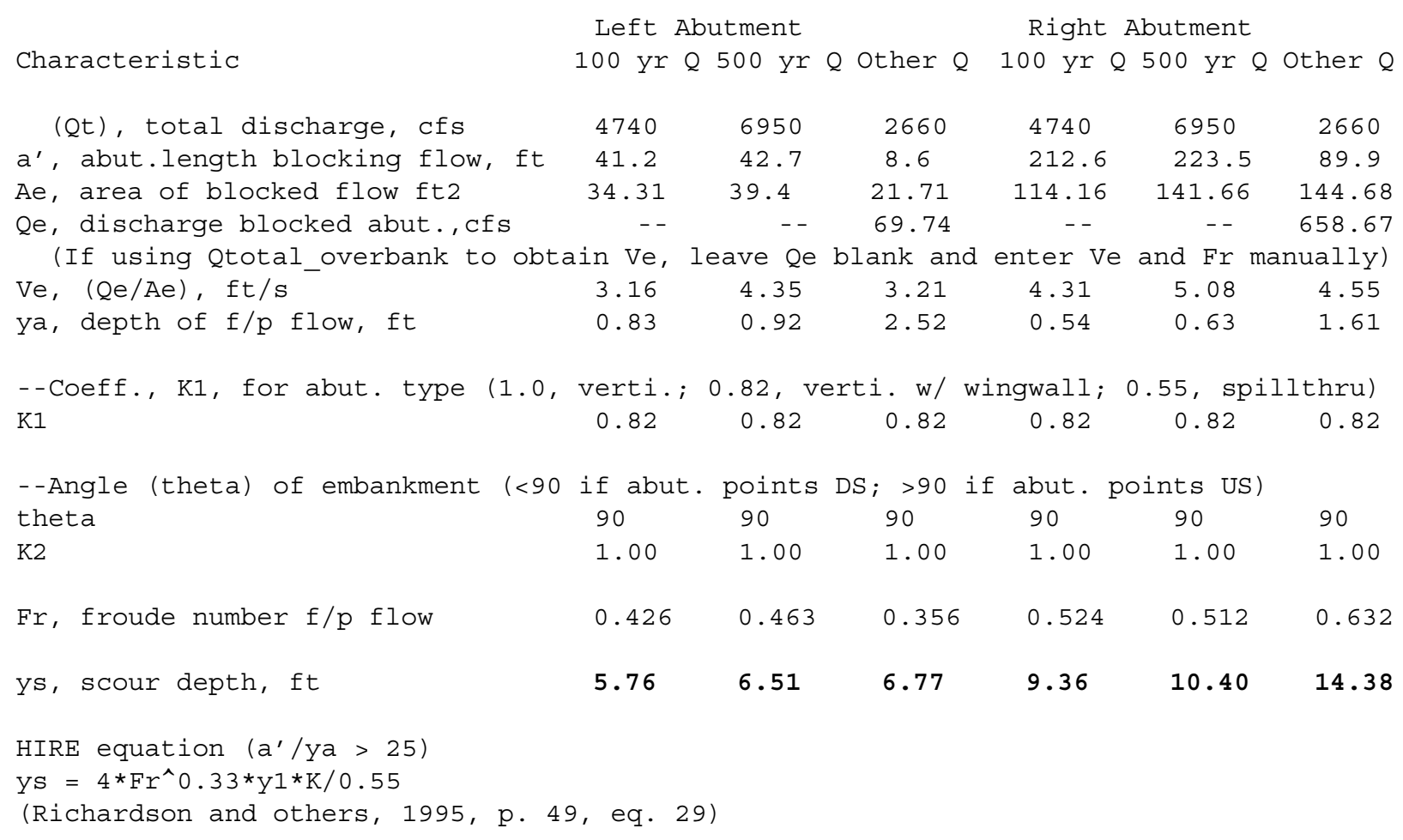




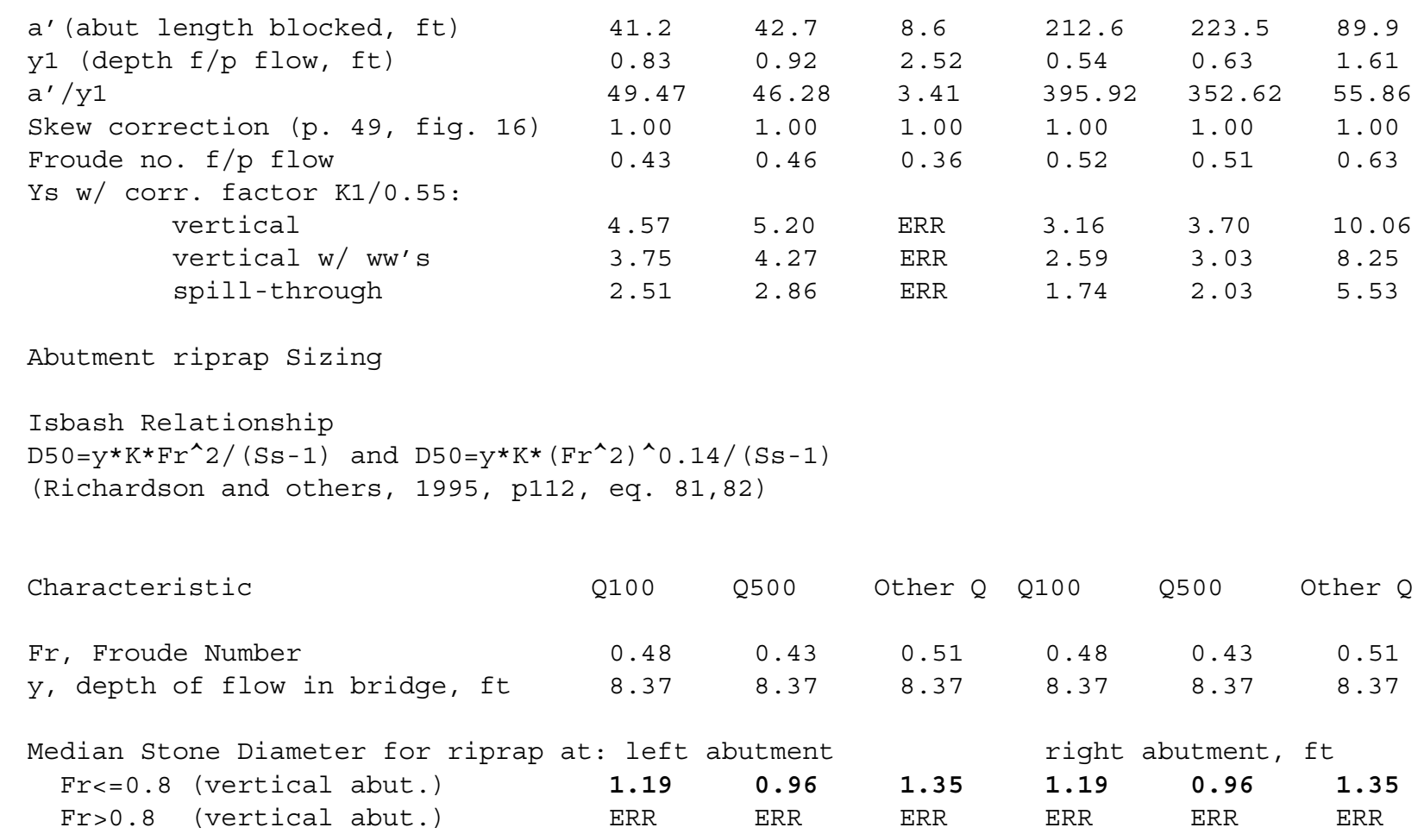

